
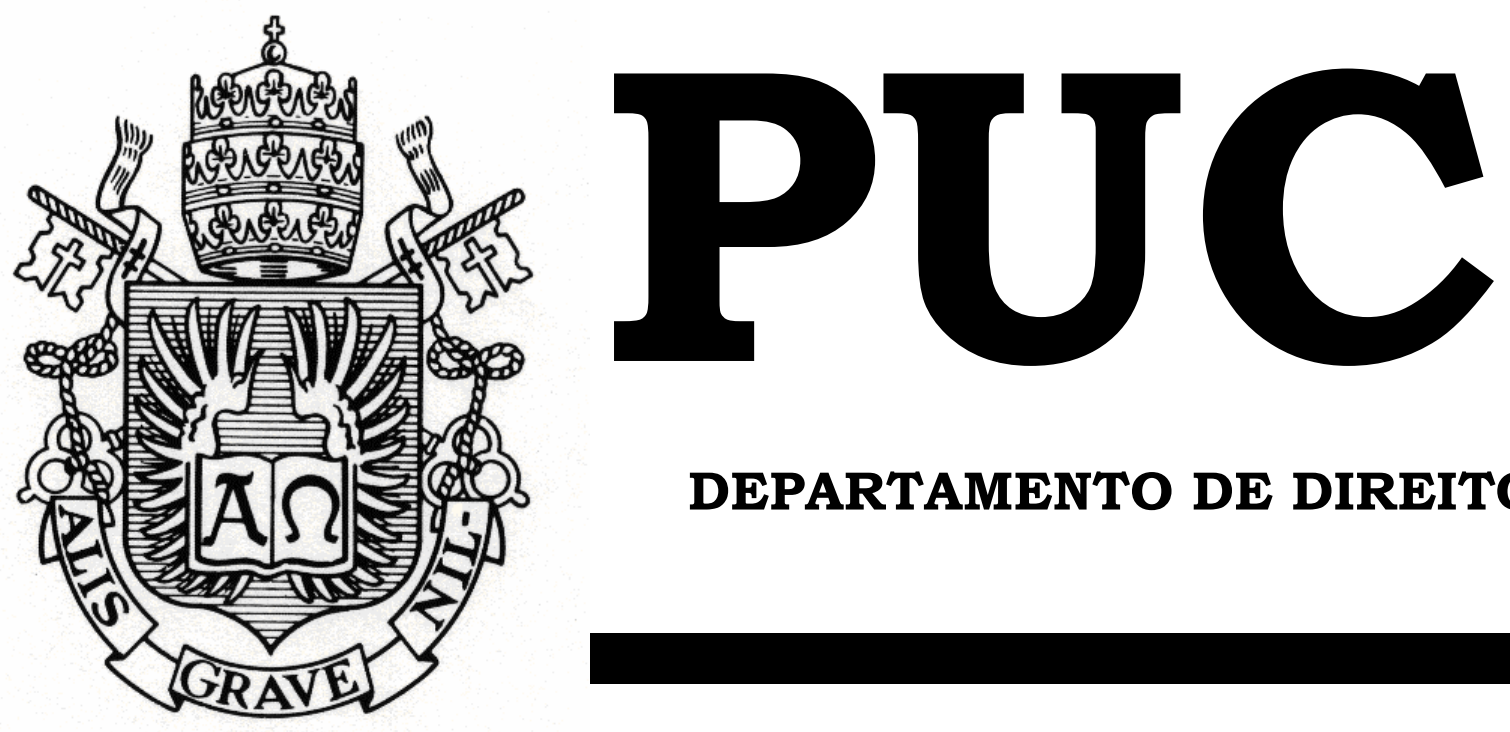

DEPARTAMENTO DE DIREITO

\title{
TEORIA DO RISCO INTEGRAL NO DANO AMBIENTAL
}

por

BRUNO MORAES GIUDICE

ORIENTADOR: OSCAR GRAÇA COUTO

2005.1

PONTIFÍCIA UNIVERSIDADE CATÓLICA DO RIO DE JANEIRO RUA MARQUÊS DE SÃO VICENTE, 225 - CEP 22453-900 RIO DE JANEIRO - BRASIL 


\title{
TEORIA DO RISCO INTEGRAL NO DANO AMBIENTAL
}

\author{
por \\ BRUNO MORAES GIUDICE
}

Monografia apresentada ao Departamento de Direito da Pontificia Universidade Católica do Rio de Janeiro (PUCRio) para a obtenção do Título de Bacharel em Direito.

Orientador(a): Oscar Graça Couto 


\section{AGRADECIMENTOS}

"De repente a gente vê que perdeu ou está perdendo alguma coisa Morna e ingênua, que vai ficando no caminho Que é escuro e frio, mas também bonito, porque é iluminado Pela beleza do que aconteceu há minutos atrás"

(Poema - Cazuza)

Não foi fácil, muitas pedras encontrei no caminho até aqui trilhado, mas consegui, lutei, venci, aqui cheguei e agora percebo o quão bonito foi percorrêlo. Porém tenho consciência de que sozinho não seria possível. Muitos contribuíram na persecução deste resultado, e justamente a eles que me sinto na obrigação de oferecer meus agradecimentos.

Em primeiro lugar aos meus professores e demais profissionais que de alguma forma certamente contribuíram, em especial àqueles que, nesta etapa final diretamente influenciaram na resolução deste trabalho.

Aos meus amigos, aqueles que incondicionalmente estiveram o tempo todo a me incentivar. Difícil descrever a importância deste apoio, mas que inegavelmente mostrou-se fundamental.

À Marília, minha namorada, constantemente me suprindo com a força necessária a continuar seguindo, nos bons e nos maus momentos, sempre ao meu lado.

E finalmente a maior razão de ser deste trabalho, agradeço a meus pais e familiares, sempre preocupados com a minha formação e evolução, fonte primeira de todo conhecimento que até aqui adquiri, responsáveis diretos pelo resultado aqui alcançado. 


\section{Resumo da obra}

Analisaremos a responsabilidade civil aplicada ao dano ambiental, tendo por objetivo identificar as peculiaridades deste instituto quando se verificar a ocorrência de uma lesão ao meio ambiente. Inicialmente identificaremos os modelos tradicionais de responsabilidade civil, definiremos, com base nas construções doutrinárias até hoje formuladas, o que significa o dano ambiental para, então, adentrarmos a ceara específica da reparação pelos danos ambientais causados. Amplamente defendida sua aplicabilidade nas hipóteses de danos causados ao meio ambiente, a teoria do risco integral será amplamente debatida, com seus contornos específicos no que diz respeito ao nexo de causalidade, às excludentes de responsabilidades e à licitude do desenvolvimento de determinada atividade potencialmente poluidora. Neste universo abordaremos princípios basilares de Direito Ambiental necessários à fundamentação do modelo de responsabilidade civil específico aqui tratado, como os princípios da prevenção e da precaução, bem como o princípio do poluidor-pagador.

Palavras-chave: Dano ambiental - Responsabilidade civil objetiva Teoria do risco integral 


\section{Sumário}

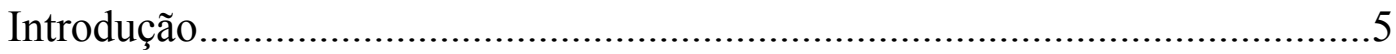

1. Responsabilidade civil

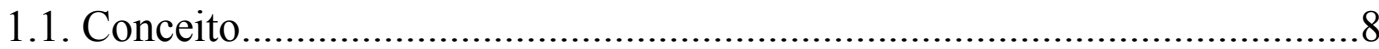

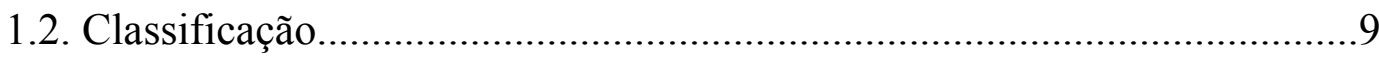

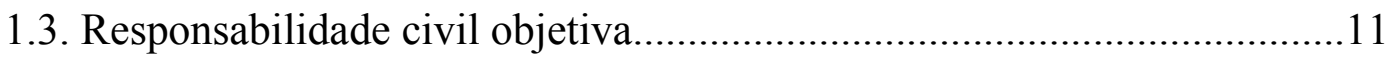

1.3.1. Breve síntese histórica..........................................................................

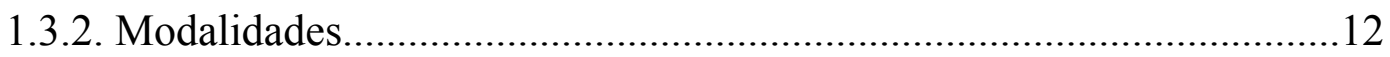

2. Dano ambiental

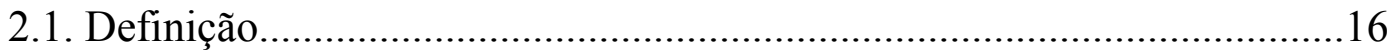

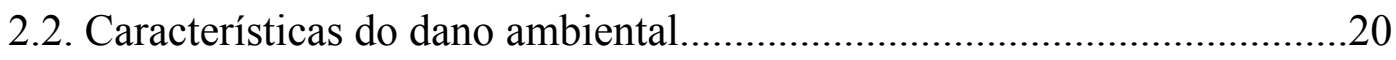

3. Princípios da responsabilidade civil ambiental

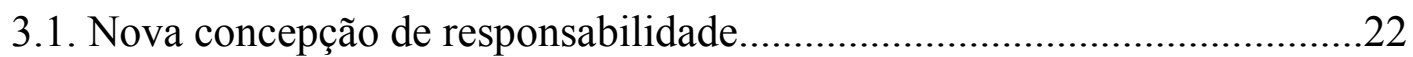

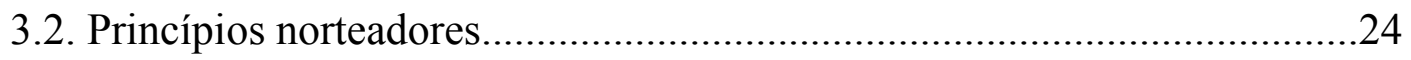

4. Teoria do risco integral

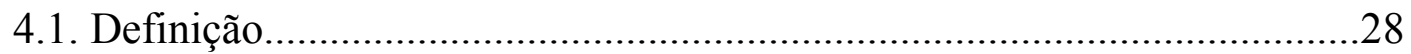

4.2. Risco integral e a tutela do meio ambiente...............................................29

5. Responsabilidade civil ambiental

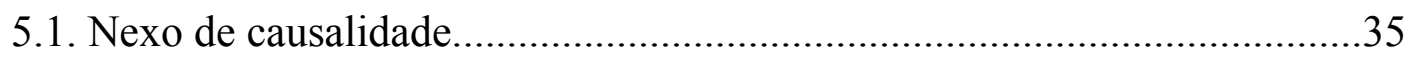

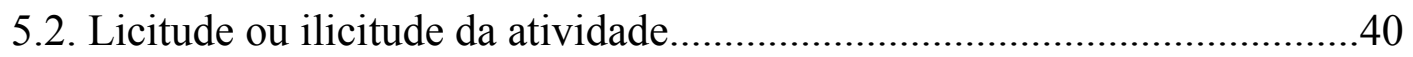

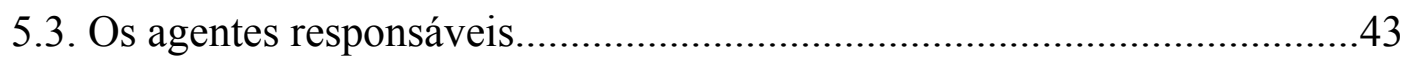

5.4. A solidariedade entre os diversos agentes..................................................47

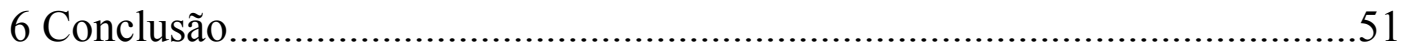

Bibliografia 


\section{Introdução}

Podemos constatar no mundo em que vivemos uma ampla e constante degradação, perpetrada pelo homem, do meio em que vive. Não representa um fenômeno atual, está intimamente ligado a sua própria existência e natureza. O homem há muito não vive em perfeita harmonia com o ambiente que está a sua volta.

A todo momento noticiam os jornais as diversas catástrofes ambientais decorrentes da atividade humana, não se pode conceber, permitir a banalização deste problema, aceitando-o como um fenômeno natural, decorrente do desenvolvimento humano.

Este quadro de degradação, como apontado, não é recente. Contudo, a prática predatória do espaço natural passou a ser objeto de preocupação por parte de vários setores da sociedade, a partir dos anos sessenta, tornando possível consolidar o temor da desenfreada degradação ambiental em sistemas normativos, com regras específicas, destinadas à tutela do meio ambiente, visando sua utilização harmoniosa.

No Brasil obtivemos grandes avanços no que diz respeito a essa preocupação. A entrada em vigor da Lei de Política Nacional do Meio ambiente (Lei 6.938/81) representou um marco no ordenamento jurídico ambiental.

Podemos afirmar que nossa legislação está bem avançada nas questões relativas à proteção do meio ambiente, ganhando tutela constitucional a partir da promulgação da Carta Magna de 1988, que alçou o meio ambiente à qualidade de bem de uso comum do povo.

A constitucionalização da problemática ambiental é um indicativo da importância deste tema, da necessidade de criação de sistemas normativos que possibilitem o resguardo do meio natural para as atuais e futuras gerações. 
Por sua vez, a adoção de normas mais rígidas na prevenção e na reparação do dano ambiental passa a ser um imperativo na busca de um desenvolvimento sustentável, sem excessiva agressão ao meio ambiente, o que permitirá uma coexistência harmônica entre o homem e o meio que o cerca.

Neste passo, a norma infraconstitucional, posteriormente recepcionada pela Constituição Federal, adotou o sistema de responsabilidade civil objetiva, independente de culpa, para os danos causados ao meio ambiente.

Desta forma, estudaremos a responsabilidade civil específica para a matéria ambiental, notadamente a aplicação da teoria do risco integral aos danos causados ao meio ambiente.

Primeiramente faremos uma análise geral sobre a responsabilidade civil, apresentando seu conceito, pressupostos e finalidade, diferenciando as diversas modalidades, focando na responsabilidade civil objetiva, sobre a qual realizaremos inicialmente um breve relato histórico, para depois explicitar suas diversas subespécies.

Em seguida abordaremos o dano ambiental, cuja conceitualização não se afigura como questão das mais fáceis. Tentaremos defini-lo, com base nos ensinamentos daqueles doutrinadores que deste tema já se ocuparam, delineando suas peculiaridades frente aos danos tradicionalmente concebidos.

As principais características do dano causado ao meio ambiente serão apresentadas neste capítulo, quando iremos explicitar sua característica difusa, a dificuldade - e algumas vezes impossibilidade - de reparação, assim como os problemas encontrados na valoração desta espécie de dano.

Bem delineados este pressupostos conceituais, finalmente poderemos adentrar a responsabilidade civil ambiental especificamente, que se apresenta como uma nova forma de responsabilização. 
Em muitos pontos esta forma de responsabilização se mostra bem diversa do modelo de responsabilidade tradicionalmente concebido, mais ampla, não mais regida pelas relações entre particulares apenas, posto que visa a tutela de um bem de uso comum do povo.

Da mesma forma, como teremos a oportunidade de salientar, a simples reparação, justificativa necessária a fundamentar a responsabilidade civil tradicional, não se apresenta mais, isoladamente, como inteiramente satisfatória para problemática ambiental.

Assim, princípios como o da prevenção, da precaução e do poluidor-pagador serão levantados, uma vez que essenciais para a completa e satisfatória concepção da responsabilidade civil ambiental.

A responsabilidade pelos danos causados ao meio ambiente, como teremos oportunidade de demonstrar, é objetiva, ou seja, independente da existência de culpa do agente causador do dano. Todavia, neste cenário específico de responsabilização deveremos enfrentar matéria não disposta expressamente em texto de lei.

Muitas são as adversidades encontradas no caminho que leva à responsabilização pelos danos ocasionados ao meio ambiente, como a própria verificação do agente causador, bem como a comprovação do nexo de causalidade entre o dano e este agente.

Frente a estas e muitas outras dificuldades é que se entende, de forma majoritária em sede doutrinária, pela aplicação da teoria do risco integral aos danos causados ao meio ambiente, cabendo-nos analisar de que forma se dará sua incidência, sobre quem e quando ela ocorrerá.

Sendo a modalidade de reparação mais rigorosa, cumpre-nos estudar como agirão determinados fatores quando aplicada esta teoria, como o nexo de causalidade - que alguns autores entendem ser desnecessário nesta modalidade de responsabilização - a licitude da atividade degradadora e os agentes responsáveis. 


\section{Responsabilidade Civil}

\subsection{Conceito}

Sendo o objeto do presente estudo, a teoria do risco integral aplicada ao dano ambiental, uma modalidade - a mais gravosa - de responsabilidade civil, cumpre, antes de adentrar os conceitos específicos desta teoria, ressaltar alguns aspectos relevantes sobre este importante ramo do Direito.

A responsabilidade civil é a forma através da qual alguém que, de alguma forma, se sentir lesado, buscará a restituição junto ao agente causador do dano, desde que presentes os pressupostos legais para a responsabilização deste ofensor.

O objetivo principal da responsabilidade civil, afirma Sérgio Cavalieri Filho, é "colocar a vítima na situação em que estaria sem a ocorrência do fato danoso" 1 , destacando que "o dano causado pelo ato ilícito rompe o equilíbrio jurídico-econômico existente entre o agente e a vítima"2.

É justamente este o fundamento da responsabilidade civil, ou seja, a necessidade de fazer retornar ao ofendido a condição que este possuía antes do evento danoso, econômica ou psicologicamente. A fundamentação da responsabilidade civil está no restabelecimento do equilíbrio econômicojurídico que encontra no dano sua causa.

Idêntico entendimento encontraremos nos ensinamentos de Paulo de Bessa Antunes, para quem "a reparação visa a fazer com que o lesado, através do recebimento de uma indenização, seja recolocado no status quo ante, como se a lesão não houvesse ocorrido" ${ }^{3}$.

${ }^{1}$ CAVALIERI FILHO, Sergio. Programa de responsabilidade civil. 5. ed. rev. aum. atual. São Paulo: Malheiros, 2004. p. 25.

${ }^{2}$ Ibid. p. 35.

${ }^{3}$ ANTUNES, Paulo de Bessa. Direito ambiental. 7. ed. Rio de Janeiro: Lúmen Juris, 2004. p. 208. 
Nosso Código Civil dispõe no art. 927 que será obrigado a reparar o dano aquele que por ato ilícito lhe der causa ${ }^{4}$. Deste dispositivo podemos extrair dois dos elementos essenciais da responsabilização civil, quais sejam, a violação de um dever jurídico e o dano. Não há como imaginar a responsabilização civil de alguém que, mesmo cometendo um ato ilícito, não causa um dano.

Por outro lado, em princípio, se alguém causa um dano a outrem, mas não se pode imputar a esta conduta nenhuma contrariedade à norma jurídica, da mesma forma não se poderá a ele imputar o dever de indenizar por este dano causado.

Além destes dois pressupostos básicos, outro importante requisito para a responsabilização de alguém é o nexo de causalidade entre a conduta do agente e o dano experimentado pela vítima. É necessário restar configurado que aquela ação ou omissão ocasionou o dano. Deve ser verificado se, excluindo-se a conduta, inexistente seria o dano, hipótese em que estará ausente este pressuposto de responsabilização.

Desta forma, como regra, sujeita a exceções, analisadas adiante, afirma-se que os elementos necessários para a responsabilização de alguém são: a conduta antijurídica (procedimento culposo do agente, por ação ou omissão), a ocorrência de um dano e o nexo de causalidade entre o dano e o agente $^{5}$.

\footnotetext{
${ }^{4}$ Art. 927 do Código Civil de 2002 assim estabelece: "Aquele que, por ato ilícito, (arts. 186 e 187), causar dano a outrem, fica obrigado a repará-lo".

${ }^{5}$ ATHIAS, Jorge Alex Nunes. Responsabilidade civil e meio ambiente: breve panorama do direito brasileiro. In: Dano ambiental: prevenção, recuperação e repressão. São Paulo: Revista dos Tribunais, 1993. p. 237.
} 


\subsection{Classificação}

Existem diversas classificações para a responsabilização da conduta do agente causador de um determinado dano. Assim, denomina-se como penal ou civil a responsabilidade classificada em razão da norma jurídica violada pela conduta do agente ${ }^{6}$.

Será contratual ou extracontratual a classificação da responsabilidade civil considerando-se "a qualidade da violação" 7 . Desta forma, se o dever de indenizar surge a partir de um vínculo obrigacional, oriundo de um acordo de vontades, será esta responsabilidade contratual. Diversamente, será extracontratual a responsabilidade quando esta decorrer de violação a "direito subjetivo, sem que entre o ofensor e a vítima preexista qualquer relação jurídica" 8 .

Contudo, classificação fundamental para o trabalho que aqui pretendemos elaborar é a que divide a responsabilidade civil em subjetiva e objetiva.

A diferenciação entre subjetiva e objetiva está no elemento principal e essencial da primeira teoria, fundada na culpa do agente causador do dano. Para que se impute a alguém o dever de indenizar pelos danos causados a outrem, antes deverá ser provado que o agente causador agiu com culpa, ou seja, deverá ser comprovado que este faltou com o dever de cautela ou agiu intencionalmente com o fim de ocasionar o dano.

$\mathrm{Na}$ Responsabilidade civil objetiva, onde prevalece a teoria do risco em relação aos atos praticados pelo agente, o pressuposto culpa é irrelevante, não há a necessidade de análise acerca da conduta do agente, se este agiu com culpa ou não.

\footnotetext{
${ }^{6}$ CAVALIERI FILHO, Sergio. Programa de responsabilidade civil. 5. ed. rev. aum. atual. São Paulo: Malheiros, 2004. p. 35-36.

${ }^{7}$ Ibid. p. 39.

${ }^{8}$ Ibid. p. 37.
} 


\subsection{Responsabilidade civil objetiva}

\subsubsection{Breve síntese histórica}

Feita esta breve análise conceitual de responsabilidade civil, bem como das diversas classificações de responsabilidade existentes em nosso ordenamento jurídico, sintetizamos o foco do presente estudo na Responsabilidade Civil Extracontratual Objetiva.

Como já salientado, na responsabilidade civil objetiva, irrelevante para caracterização do dever de indenizar é o elemento culpa, podendo este estar ou não presente.

Este modelo surgiu a partir das revoluções tecnológicas experimentadas pelo homem nos últimos dois séculos, notadamente a Revolução Industrial, quando a sociedade passou a conviver com elementos que ocasionaram um distanciamento entre a pessoa lesada e aquele que deu causa ao dano, como, por exemplo, a utilização de máquinas nas indústrias.

Passou a ser muito difícil provar a culpa daquele que deu causa ao dano, pois este passou a não mais ocasionar diretamente a lesão. Assim, por exemplo, o funcionário de uma fábrica, ao se acidentar com o maquinário não conseguia estabelecer um liame causal entre a conduta do dono daquela fábrica e a sua lesão, surgindo desses acidentes ocorridos no trabalho a idéia de insuficiência da culpa como elemento da responsabilidade, do dever de reparar ${ }^{9}$.

A ocorrência de diversas situações que não permitiam à pessoa lesada obter o ressarcimento pelo dano causado justamente em razão da impossibilidade de se averiguar a culpa do agente é que possibilitou a

${ }^{9}$ CAVALIERI FILHO, Sergio. Programa de responsabilidade civil. 5. ed. rev. aum. atual. São Paulo: Malheiros, 2004. p. 35-36. 
transposição, em alguns casos específicos, da responsabilidade subjetiva, fundada na culpa, para a responsabilidade objetiva ${ }^{10}$.

Essa necessidade de relevar a culpa em algumas hipóteses deu origem à teoria do risco, através da qual o dever de indenizar surge a partir do desenvolvimento de determinada atividade potencialmente causadora de um dano. Dispensa-se com esta teoria "qualquer juizo de valor sobre a culpa do responsável, que é aquele que materialmente causou o dano" ${ }^{11}$.

\subsubsection{Modalidades}

Como é de conhecimento de todos, certos empreendimentos envolvem uma série de riscos os quais deverão ser assumidos exclusivamente pelo empreendedor, como a receptividade do consumidor ao lançamento de um determinado produto. Com a teoria do risco este empreendedor passa a incorporar à sua cadeia de produção, além dos riscos econômicos inerentes a qualquer empreendimento, também aqueles resultantes dos danos a outros causados, dela decorrentes.

Nesta linha, Sérgio Cavalieri Filho aponta cinco modalidades destacadas como subespécies para a teoria do risco da atividade. São elas:

a) Risco Profissional - específico para os danos decorrentes da atividade profissional exercida pelo lesado;

b) Risco Excepcional - estarão inseridos aqueles danos que "escapam da atividade comum da vítima", mesmo que esta atividade não se relacione com o trabalho que o lesado exerce.

\footnotetext{
${ }^{10}$ ATHIAS, Jorge Alex Nunes. Responsabilidade civil e meio ambiente: breve panorama do direito brasileiro. In: Dano ambiental: prevenção, recuperação e repressão. São Paulo: Revista dos Tribunais, 1993. p. 237.

${ }^{11}$ CAVALIERI FILHO, Sergio. Programa de responsabilidade civil. 5. ed. rev. aum. atual. São Paulo: Malheiros, 2004. p. 145.
} 
c) Risco Proveito - a justificativa desta subespécie é a vantagem que o agente causador do dano retira de sua atividade, devendo ser responsabilizado, via de conseqüência, também pelos danos dela decorrentes. Encontra muitas críticas em razão da dificuldade de se provar o benefício que o agente retira da atividade, bem como a conceitualização do que seja o proveito.

d) Risco Criado - Incorpora a teoria do risco proveito, porém aqui não será necessário, como requisito, um proveito qualquer, pois a simples colocação de uma atividade em funcionamento já seria suficiente para sujeitar o agente aos danos dela provenientes, configurado ou não qualquer proveito que ele tenha obtido.

e) Risco Integral - Por último, a teoria mais gravosa para o causador do dano, “modalidade extremada" segundo Sérgio Cavalieri Filho. De acordo com esta teoria, objeto do presente estudo, não se admite nenhuma das excludentes de responsabilidade, notadamente o caso fortuito, a força maior, a culpa exclusiva da vítima ou fato de terceiro ${ }^{12}$.

Passadas em linhas gerais as cinco teorias, ou subespécies, que fundamentam a responsabilidade civil objetiva, devemos ressaltar, ainda, que em nosso ordenamento jurídico prevalece, como regra geral, a responsabilidade subjetiva, na qual a comprovação da culpa do agente representa requisito indispensável.

Contudo, podemos afirmar que cada vez mais a responsabilidade civil objetiva, ainda excepcional, ganha espaço em nosso ordenamento, principalmente com o Código de Defesa do Consumidor, ao estabelecer que os danos causados aos consumidores, seja pelo fato do produto

\footnotetext{
${ }^{12}$ CAVALIERI FILHO, Sergio. Programa de responsabilidade civil. 5. ed. rev. aum. atual. São Paulo:
} Malheiros, 2004. p. 146-147. 
seja pelo fato do serviço, deverão ser reparados, independente da existência de culpa $^{13}$.

Sobre a ampliação do campo de incidência da responsabilidade civil objetiva, bem como sua justificativa, defende com maestria Sérgio Cavalieri Filho que "quem se dispõe a exercer alguma atividade perigosa terá que fazê-lo com segurança, de modo a não causar dano a ninguém, sob pena de ter que por ele responder independente de culpa" 14 .

Como já salientado, a responsabilidade civil objetiva representa, em nosso ordenamento jurídico uma exceção da qual a responsabilidade civil subjetiva, fundada na culpa, ainda é a regra, devendo estar expressamente prevista em lei para que seja configurada.

Nesta esteira, além do Código de Defesa do Consumidor, diversos outros textos normativos imputam ao agente causador do dano a obrigação de indenizá-lo, independente da existência de culpa, como, por exemplo, o $\S 6^{\circ}$ do art. 37 da Constituição, referente à responsabilidade das pessoas jurídicas de direito público e as de direito privado prestadoras de serviços públicos ${ }^{15}$; além do art. $14, \S 1^{\circ}$, da Lei $6.938 / 81$, que trata dos danos causados ao meio ambiente, entre outros dispositivos legais que da mesma forma estipulam o dever de indenizar independente de culpa do ofensor. ${ }^{16}$

\footnotetext{
${ }^{13}$ Art. 12, caput, do Código de Defesa do Consumidor: O fabricante, o produtor, o construtor, nacional ou estrangeiro, e o importador respondem, independentemente da existência de culpa, pela reparação dos danos causados aos consumidores por defeitos decorrentes de projeto, fabricação, construção, montagem, fórmulas, manipulação, apresentação ou acondicionamento de seus produtos, bem como por informações insuficientes ou inadequadas sobre sua utilização e riscos.

Art. 14, caput do CDC: O fornecedor de serviços responde, independentemente da existência de culpa, pela reparação dos danos causados aos consumidores por defeitos relativos à prestação de serviços, bem como por informações insuficientes ou inadequadas sobre sua fruição e riscos.

${ }^{14}$ CAVALIERI FILHO, Sergio. Programa de responsabilidade civil. 5. ed. rev. aum. atual. São Paulo: Malheiros, 2004. p. 148.

${ }^{15}$ Art. $37, \S 6^{\circ}$ da Constituição Federal: As pessoas jurídicas de direito público e as de direito privado prestadoras de serviços públicos responderão pelos danos que seus agentes, nessa qualidade, causarem a terceiros, assegurado o direito de regresso contra o responsável nos casos de dolo ou culpa.

${ }^{16}$ CAVALIERI FILHO, Sergio. Programa de responsabilidade civil. 5. ed. rev. aum. atual. São Paulo: Malheiros, 2004. p. 152-154.
} 
Com a entrada em vigor do Código Civil, em janeiro de 2003, bem alargadas passaram a ser as hipóteses de objetivação da responsabilidade civil, através da criação de um amplo leque de cláusulas que acabaram por diminuir o campo de incidência da teoria subjetivista, como é o caso do parágrafo único do art. $927^{17}$ e do art. $931^{18}$ deste diploma legal.

Porém, cumpre ressaltar que, embora ampliado o campo de incidência da responsabilidade civil objetiva, podendo-se defender até uma maior incidência, permanece esta como exceção à regra da responsabilidade civil subjetiva, posto que apenas poderá ser utilizada quando prevista em lei.

Após esta breve análise da responsabilidade civil em nosso ordenamento jurídico, focada na responsabilidade civil objetiva, dedicaremos agora um capítulo à conceitualização do dano ambiental, um dos requisitos básicos para que possa ser configurado o dever de indenizar.

\footnotetext{
${ }^{17}$ Art. 927, parágrafo único do Código Civil: Haverá obrigação de reparar o dano, independentemente de culpa, nos casos especificados em lei, ou quando a atividade normalmente desenvolvida pelo autor do dano implicar, por sua natureza, risco para os direitos de outrem.

${ }^{18}$ Art. 931 do Código Civil: Ressalvados outros casos previstos em lei especial, os empresários individuais e as empresas respondem independentemente de culpa pelos danos causados pelos produtos postos em circulação.
} 


\section{Dano Ambiental}

\subsection{Definição}

Ao estudarmos a responsabilidade civil destacamos como elementos indispensáveis para a imposição da obrigação de indenizar a violação de um dever jurídico e o dano, além do liame causal que liga a conduta do agente ofensor ao dano provocado.

Sem dano não subsiste o dever de reparar. Na verdade pode-se afirmar que não há o que reparar se nenhum dano foi ocasionado. "Pode haver responsabilidade sem culpa, mas não pode haver responsabilidade sem dano" 19. Tal assertiva se alinha ao entendimento anteriormente esposado, de que o fim almejado pela responsabilização civil é o de restabelecer o equilíbrio entre ofensor e ofendido, quebrado quando da ocorrência do dano.

De uma forma genérica, o dano é hoje conceituado em nossa doutrina como "a subtração ou diminuição de um bem jurídico", seja este bem patrimonial ou moral, "integrante da personalidade da vítima" 20.

Com pertinência explica Paulo de Bessa Antunes sobre a indispensabilidade do dano para ser configurado o dever de indenizar: " $a$ toda evidência que não se pode definir qual o ressarcimento devido se o dano a ser reparado não estiver suficientemente classificado, especificado e quantificado. Com efeito, sem a existência do dano, inexiste responsabilidade" ${ }^{21}$.

Esta é a descrição do dano em linhas gerais. Devemos agora analisar o dano causado ao meio ambiente, levando-se em consideração o prejuízo que este acarreta não só ao patrimônio privado, particular, mas a toda

\footnotetext{
${ }^{19}$ CAVALIERI FILHO, Sergio. Programa de responsabilidade civil. 5. ed. rev. aum. atual. São Paulo: Malheiros, 2004. p. 88.

${ }^{20}$ Ibid. p. 89.

${ }^{21}$ ANTUNES, Paulo de Bessa. Direito ambiental. 7. ed. Rio de Janeiro: Lúmen Juris, 2004. p. 239.
} 
a coletividade, decorrência da característica difusa, indivisível, do patrimônio ambiental.

Não é das tarefas mais fáceis, todavia, tal conceitualização, encontrando certa dificuldade quem se propõe ao estudo do tema. Sobre o assunto assinala Paulo de Bessa Antunes que "não existe um critério para fixação do que, efetivamente, constitui o dano ambiental e como este deve ser reparado", deixando visíveis as imprecisões e dificuldades que circundam o conceito de dano ao meio ambiente ${ }^{22}$.

Antônio Herman Benjamin conceitua o dano ao meio ambiente como a "alteração, deterioração ou destruição, parcial ou total, de quaisquer dos recursos naturais, afetando adversamente o homem elou a natureza". Salienta o autor que neste conceito estarão incluídas apenas as alterações negativas perpetradas contra o meio ambiente ${ }^{23}$.

A Constituição Federal de 1988 estabelece no artigo 225 que "todos têm direito ao meio ambiente ecologicamente equilibrado". Pode-se afirmar que qualquer alteração que resulte em um desequilíbrio resultará em dano ao meio ambiente. Resta, então, estabelecer o conceito de meio ambiente ecologicamente equilibrado.

A Lei de Política Nacional do Meio Ambiente define a degradação ambiental como a alteração adversa das características do meio ambiente. Poluição está definida como a degradação da qualidade ambiental que resulta de atividades que direta ou indiretamente: a) prejudiquem a saúde, a segurança e o bem-estar da população; b) criem condições adversas às atividades sociais e econômicas; c) afetem desfavoravelmente a biota; d) afetem as condições estéticas e sanitárias do meio ambiente; e) lancem matéria e energia em desacordo com os padrões ambientais estabelecidos.

\footnotetext{
${ }^{22}$ Ibid. p. 247.

${ }^{23}$ BENJAMIN, Antonio Herman V. Responsabilidade civil pelo dano ambiental. Revista de Direito Ambiental, São Paulo, n. 9, p. 5-52, jan/mar. 1998. p. 48.
} 
Deste dispositivo extrai-se que a poluição é qualquer alteração adversa das características do meio ambiente que resultarem em quaisquer dos malefícios acima elencados.

Contudo, deve-se estar atento ao termo "condições adversas", posto que o subjetivismo peculiar de tal expressão poderá criar divergência no entendimento do que seja o dano ambiental. Assim uma alteração que acabe com determinado ecossistema em prol de um projeto paisagístico, por exemplo, pode trazer a falsa impressão de que tal alteração foi positiva quando, na verdade, pela ótica da diversidade biológica natural daquele ecossistema, tal alteração mostrou-se negativa ${ }^{24}$.

Conjugando o dispositivo constitucional com a lei infraconstitucional acima referida pode-se afirmar que qualquer ação ou omissão que acarrete um desequilíbrio negativo ao "conjunto de condições, leis, influências e interações de ordem física, química e biológica, que permite, abriga e rege a vida em todas as formas" ${ }^{25}$, estará causando dano ao meio ambiente.

Mantendo esta linha, bem define Adalberto Pasqualotto o dano ecológico como sendo "toda degradação ambiental que atinja o homem na sua saúde, segurança e bem-estar ou nas atividades econômicas; as formas de vida animal e vegetal, bem como o meio ambiente, tanto do ponto de vista físico quanto estético" 26 .

Com maestria não se resume o autor a uma definição reducionista e ultrapassada que apenas possibilitaria a configuração do dano ambiental quando este atingisse tão somente o homem, devendo ser igualmente

\footnotetext{
${ }^{24}$ Ibid. p. 49.

${ }^{25}$ Lei $n^{\circ} 6.938 / 81$, art. $3^{\circ}$, inciso I.

${ }^{26}$ PASQUALOTTO, Adalberto. Responsabilidade civil por dano ambiental: considerações de ordem material e processual. In: DANO ambiental: prevenção, reparação e repressão. São Paulo: Revista dos Tribunais, 1993. p. 454.
} 
tutelada a defesa do meio ambiente quando não diretamente o homem é afetado.

Neste sentido aponta Antônio Herman Benjamin. O autor ressalta a necessidade de se destacar a danosidade que afeta o homem, atingindo, via de conseqüência, a natureza, daquela danosidade que alcança apenas a natureza, sem resultados negativos diretos para o homem. O dano ambiental, abandonando-se uma concepção estritamente antropocêntrica, será experimentado, caracterizado, também naquelas hipóteses nas quais apenas o meio ecológico suporta os prejuízos.

A partir deste entendimento conclui o autor que "os danos ambientais são gênero, nos quais vamos localizar danos pessoais (patrimoniais e morais) e ecológicos (também conhecidos por ambientais estrictu sensu, ecológicos puros ou contra a natureza)" 27.

Para Édis Milaré não há em nossa legislação uma definição completa do que seja efetivamente o dano ambiental, estando delineadas as noções de degradação da qualidade ambiental (a alteração adversa do meio ambiente) e poluição (a degradação da qualidade ambiental resultante de atividades que direta ou indiretamente darão causas às hipóteses previstas no artigo $3^{\circ}$, inciso III, da Lei $\left.{ }^{\circ} 6.938 / 1981\right)$.

O autor conceitua o dano ambiental como a lesão aos recursos ambientais - atmosfera, águas interiores, superficiais e subterrâneas, estuários, o mar territorial, o solo, o subsolo, os elementos da biosfera, a fauna e a flora com a conseqüente degradação, ou seja, a alteração adversa ou in pejus do equilíbrio ecológico e da qualidade de vida ${ }^{28}$.

Como podemos observar, não se apresenta como uma questão totalmente solidificada em nossa doutrina a conceitualizaçao do que seja o

\footnotetext{
${ }^{27}$ BENJAMIN, Antonio Herman V. Responsabilidade civil pelo dano ambiental. Revista de Direito Ambiental, São Paulo, n. 9, p. 5-52, jan/mar. 1998. p. 49-51.

${ }^{28}$ MILARÉ, Édis. Direito do ambiente. 2. ed. rev. aum. atual. São Paulo: Revista dos Tribunais, 2001. p. 421 .
} 
dano ambiental, sendo certo que a legislação elaborada, nesta matéria, apresenta um direcionamento capaz de nos guiar para uma mais eficiente responsabilização dos agentes causadores dos imensos males que verificamos no estágio atual da nossa civilização, sem, contudo, exaurir a matéria.

\subsection{Características do dano ambiental}

Como salientado anteriormente, uma das principais características do dano ambiental é a difusividade. Não há como imaginar de outra forma este dano, pois a própria Constituição Federal assim caracteriza o meio ambiente, "como bem de uso comum do povo" 29.

A partir deste conceito pode-se afirmar que os efeitos ocasionados pelo dano ambiental atingirão toda a coletividade, e não, apenas, indivíduos ou grupo de indivíduos determinados.

Podemos extrair este conceito a partir dos ensinamentos de Édis Milaré, para quem o dano ambiental, ao contrário do que ocorre na hipótese de um dano tradicional, como um acidente de trânsito, "...afeta, necessariamente, uma pluralidade difusa de vítimas, mesmo quando alguns aspectos particulares da sua danosidade atingem individualmente certos sujeitos" 30 .

A dificuldade de reparação também é uma característica dos danos causados ao meio ambiente, isto quando não impossível, devendo este conceito ser utilizado para movimentar todos os esforços possíveis da sociedade no sentido de se prevenir possíveis danos.

\footnotetext{
${ }^{29}$ Constituição Federal, art. 225: Todos têm direito ao meio ambiente ecologicamente equilibrado, bem de uso comum do povo e essencial à sadia qualidade de vida, impondo-se ao Poder Público e à coletividade o dever de defendê-lo e preservá-lo para as presentes e futuras gerações.

${ }^{30}$ MILARÉ, Édis. Direito do ambiente. 2. ed. rev. aum. atual. São Paulo: Revista dos Tribunais, 2001. p. 423 .
} 
Por sua dificuldade, podemos afirmar que, em relação ao dano ambiental, quando este for efetivado, sua reparação será sempre incerta e, como salienta Álvaro Mirra, quando possível se mostrará excessivamente custosa $^{31}$.

Quaisquer políticas voltadas para atividades meramente reparatórias se apresentarão insuficientes em razão desta dificuldade de reparação dos danos causados ao meio ambiente, devendo a atividade reparatória ser sempre conjugada com políticas preventivas e repressivas ${ }^{32}$.

Completa Antônio Herman Benjamin que as diversas formas de proteção ao meio ambiente, para que produzam resultados satisfatórios, devem funcionar de maneira integrada, com o uso de sanções civis, administrativas e penais ${ }^{33}$.

A dificuldade de se valorar o dano ambiental é a terceira característica fundamental. Assevera Édis Milaré que, “mesmo que levado avante o esforço reparatório, nem sempre é possível, no estágio atual do conhecimento, o cálculo da totalidade do dano ambiental', destacando ainda que, "freqüentemente, só o decurso do tempo pode dar testemunho da recuperação do ecossistema atingido" 34 .

\footnotetext{
${ }^{31}$ MIRRA, Álvaro Luiz Valery. Princípios fundamentais do direito ambiental. Revista de Direito Ambiental, São Paulo, n. 2, p. 50-66. 1996. p. 61.

${ }^{32}$ Ibid. p. 423-424

${ }^{33}$ BENJAMIN, Antonio Herman V. Responsabilidade civil pelo dano ambiental. Revista de Direito Ambiental, São Paulo, n. 9, p. 5-52, jan/mar. 1998. p. 10.

${ }^{34}$ MILARÉ, Édis. Direito do ambiente. 2. ed. rev. aum. atual. São Paulo: Revista dos Tribunais, 2001. p. 424.
} 


\section{Princípios Da Responsabilidade Civil Ambiental}

\subsection{Nova concepção de responsabilidade}

Uma das principais características do dano ambiental é sua difícil - quando não impossível - reparação. Por séculos a ação do homem, muito distante de uma relação harmoniosa com o meio ambiente, apenas se deu com intuito de explorá-lo, incessantemente, sem se preocupar com o restabelecimento de seu equilíbrio natural.

Com o agravamento da degradação ao meio ambiente surgiu o interesse do Direito por sua tutela, por sua proteção, "destruímos a potabilidade da água de abastecimento público e transformamos em cinzas habitats inteiros" 35 . Era preciso mudar o panorama da relação entre o homem e o meio que o cerca.

A simples obrigatoriedade de reparação do dano causado ao meio ambiente, isoladamente e/ou concebida em conformidade com os pressupostos tradicionais de responsabilidade civil muitas vezes se mostrara insuficiente e, portanto, ineficiente para a resolução do caótico quadro ambiental que hoje presenciamos.

O caráter reparatório da responsabilidade civil continua presente, porém não mais se apresenta totalmente satisfatório, pois este deve também ser visto por uma ótica preventiva, que consiste no estímulo aos agentes causadores do dano de buscarem formas menos perigosas para o exercício de sua atividade.

$\mathrm{Na}$ responsabilidade pelos danos ambientais os fatores tradicionalmente concebidos para a responsabilidade civil tiveram de ser alterados, dando-se uma maior relevância à sua capacidade preventiva - que

\footnotetext{
${ }^{35}$ BENJAMIN, Antonio Herman V. Responsabilidade civil pelo dano ambiental. Revista de Direito Ambiental, São Paulo, n. 9, p. 5-52, jan/mar. 1998. p. 7.
} 
passou a ser característica prioritária em matéria ambiental - e expiatória, voltando uma maior carga de preocupação com os eventos futuros, sem se descuidar dos pretéritos, através da reparação ${ }^{36}$.

Mantendo-se o dano configurado como um dos pressupostos básicos de responsabilização civil, visualiza-se seu caráter preventivo na demonstração do peso econômico que sobre os ombros do ofensor recairá, tornando cogente àquelas atividades potencialmente poluidoras alterar seu modus operandi com vistas a impedir a ocorrência do dano, ou, quando impossível, mitigar seus efeitos. Define Paulo Affonso Leme Machado:

"o direito ambiental engloba as duas funções da responsabilidade civil objetiva: a função preventiva procurando, por meios eficazes, evitar o dano - e a função reparadora - tentando reconstituir elou indenizar os prejuizos ocorridos" ${ }^{, 37}$.

Seja pela reparação, seja pela prevenção, não será mais toda a coletividade quem arcará com os prejuízos de um dano decorrentes, mas tão somente aqueles que se beneficiam da degradação ambiental. Afirma Antônio Herman Benjamin que "a responsabilidade civil é vista como uma das técnicas de incorporação das chamadas externalidades ambientais ou custos sociais ambientais decorrentes da atividade produtiva" 38 .

No mesmo sentido aponta Annelise Monteiro Steigleder, para quem a responsabilidade civil, no plano econômico, serve como "fundamento para a internalização das externalidades ambientais negativas" 39.

\footnotetext{
${ }^{36}$ BENJAMIN, Antonio Herman V. Responsabilidade civil pelo dano ambiental. Revista de Direito Ambiental, São Paulo, n. 9, p. 5-52, jan/mar. 1998. p. 15.

${ }^{37}$ MACHADO, Paulo Affonso Leme. Direito ambiental brasileiro. 12 ed. São Paulo: Malheiros Editores, 2004. p. 331.

${ }^{38}$ BENJAMIN, Antonio Herman V. Responsabilidade civil pelo dano ambiental. Revista de Direito Ambiental, São Paulo, n. 9, p. 5-52, jan/mar. 1998. p. 16.

${ }^{39}$ STEIGLEDER, Annelise Monteiro. Responsabilidade civil ambiental: as dimensões do dano ambiental no direito brasileiro. Porto Alegre: Livraria do Advogado, 2004. p. 183.
} 
A partir desta necessidade de tornar efetiva a tutela do meio ambiente, coibindo as práticas que possam causar significativo dano ambiental, novos princípios surgem para fundamentar esta nova concepção de responsabilidade civil.

\subsection{Princípios norteadores}

Quatro são os princípios, já bem consolidados em matéria ambiental, e que agora são inseridos como bases principiológicas da responsabilidade civil por danos causados ao meio ambiente: a preocupação com as gerações futuras, os princípios da precaução e da prevenção, e o princípio do poluidor-pagador.

A Constituição Federal estabelece que todos têm direito ao meio ambiente ecologicamente equilibrado, devendo este ser preservado, não só para as gerações presentes, como também para as futuras.

As gerações futuras têm o direito de usufruir, pelo menos, da mesma qualidade de vida de que usufruímos hoje, e este dever faz com que se amplie a função da responsabilidade civil, uma vez que a reparação dos danos ambientais também estará voltada para estas gerações.

É importante afirmar que este conceito de preocupação com o futuro não se justifica exclusivamente com a defesa dos interesses dos seres humanos, mas também pelo respeito pelo sistema natural e conseqüente dever de proteger o meio ambiente. O homem é "a única espécie capaz de planejar significativamente sua relação com o ambiente, podendo utilizar esta capacidade para a construção de uma base sustentável ou para o exaurimento dos recursos naturais" ${ }^{40}$.

\footnotetext{
${ }^{40}$ STEIGLEDER, Annelise Monteiro. Responsabilidade civil ambiental: as dimensões do dano ambiental no direito brasileiro. Porto Alegre: Livraria do Advogado, 2004. p. 183,185.
} 
Por certo é que, quando se impinge ao causador do dano ambiental o dever de repará-lo, além da reconstituição do bem lesado, quando possível, procura-se também garantir às futuras gerações a mesma qualidade de vida proporcionada às presentes, que se tornam guardiãs da natureza. Justifica Paulo Affonso Leme Machado o princípio do poluidor-pagador:

"o poluidor que usa gratuitamente o meio ambiente para nele lançar os poluentes invade a propriedade pessoal de todos os outros que não poluem, confiscando o direito de propriedade alheia" ${ }^{41}$.

Os princípios da precaução e da prevenção representaram as maiores dificuldades de adequação da responsabilidade civil tradicional aos objetivos da tutela do meio ambiente, isto porque a responsabilidade civil é tradicionalmente concebida “...como instrumento post factum, destinado à reparação e não à prevenção dos danos" ${ }^{42}$.

A responsabilidade civil era destinada simplesmente à restituição do lesado ao status que este gozava antes da ocorrência do dano. Seu objetivo era a reparação, sendo indissociável a verificação da ocorrência de uma lesão para a configuração do dever de indenizar. No modelo tradicional não havia relação da precaução e da prevenção com a responsabilização por um dano já ocasionado.

Pelo princípio da precaução entende-se a preocupação, a cautela, que deve haver diante de perigos desconhecidos, mas não impossíveis de ocorrerem, diferentemente do que se verifica com no princípio da prevenção, onde os riscos já são conhecidos, ou porque já ocorreram, ou porque foram identificados através de estudos previamente realizados.

\footnotetext{
${ }^{41}$ MACHADO, Paulo Affonso Leme. Direito ambiental brasileiro. 12 ed. São Paulo: Malheiros Editores, 2004. p. 331.

${ }^{42}$ BENJAMIN, Antonio Herman V. Responsabilidade civil pelo dano ambiental. Revista de Direito Ambiental, São Paulo, n. 9, p. 5-52, jan/mar. 1998. p. 8.
} 
Os princípios da precaução e da prevenção atuam, pois, justamente com o objetivo de se evitar novos danos através da responsabilização de um agente, demonstrando-se aos demais agentes, públicos ou particulares, cujas atividades são potencialmente poluidoras, o peso da responsabilidade civil por danos causados ao meio ambiente, sendo aí também identificado seu caráter expiatório.

Édis Milaré destaca que são as duas formas de reparar o dano ambiental a recuperação ou retorno ao status quo ante e a indenização em dinheiro, sendo que esta concepção de reparação possui um duplo objetivo: coibir atividades que causem prejuízos ao meio ambiente e reconstituir o patrimônio lesado, seja o patrimônio individual ou o coletivo. ${ }^{43}$

A última base da responsabilidade civil ambiental é o princípio do poluidor-pagador, através do qual aquele que der causa ao dano ambiental deverá arcar com os custos de sua reparação, bem como com os custos de prevenção de acidentes ambientais.

Tal princípio representa, para Annelise Monteiro Steigleder, a internalização - mencionada anteriormente - das externalidades ambientais negativas, o que se faz através da imposição, às fontes poluidoras, da obrigação de "incorporar em seu processo produtivo os custos com prevenção, controle e reparação dos impactos ambientais".

Defende a autora que este princípio não é destinado à reparação somente, mas primordialmente à prevenção dos danos ambientais. ${ }^{44}$

Sendo certo que os prejuízos ambientais são socializados e os lucros da produção são privatizados, como, com pertinência, afirma Jorge Alex

\footnotetext{
${ }^{43}$ MILARÉ, Édis. Direito do ambiente. 2. ed. rev. aum. atual. São Paulo: Revista dos Tribunais, 2001. p. 425.

${ }^{44}$ STEIGLEDER, Annelise Monteiro. Responsabilidade civil ambiental: as dimensões do dano ambiental no direito brasileiro. Porto Alegre: Livraria do Advogado, 2004. p. 192.
} 
Nunes Athias ${ }^{45}$, deve-se buscar, através da responsabilidade civil, fundamentada neste princípio, a internalização, a também privatização dos custos com a reparação do meio ambiente degradado.

Não se pode conceber, porém, que tal princípio represente uma permissibilidade para poluir, do tipo "paguei, posso poluir". Muito pelo contrário, em primeiro lugar ele objetiva que os agentes econômicos incorporem em seus processos produtivos os custos da produção, levando-se em conta a capacidade poluidora de sua atividade, e, caso venha a se configurar o dano, deverão então assumi-lo, pagando a conta da reparação ${ }^{46}$.

Tal princípio encontra-se bem solidificado em nossa legislação, notadamente na Política Nacional de Meio Ambiente (Lei n ${ }^{\circ}$ 6.938/1981), bem como na Constituição da República, que estabelecem a responsabilidade do poluidor pelos prejuízos causados ao meio ambiente.

Solidificados os princípios norteadores da responsabilidade civil ambiental, a questão passa a ser a extensão dessa responsabilidade, se haverá alguma hipótese que exima o poluidor de arcar com o elevado custo ambiental de sua atividade produtiva, bem como quais serão os agentes responsáveis.

\footnotetext{
${ }^{45}$ ATHIAS, Jorge Alex Nunes. Responsabilidade civil e meio ambiente: breve panorama do direito brasileiro. In: DANO ambiental: prevenção, recuperação e repressão. São Paulo: Revista dos Tribunais, 1993. p. 246.

${ }^{46}$ MILARÉ, Édis. Direito do ambiente. 2. ed. rev. aum. atual. São Paulo: Revista dos Tribunais, 2001. p. 116.
} 


\section{Teoria Do Risco Integral}

\subsection{Definição}

A teoria do risco integral apresenta-se como a mais gravosa modalidade de responsabilidade civil. Consiste em imputar a um ente causador de um dano o dever de repará-lo, independentemente da apuração de culpa, na qual não se admite nenhuma das excludentes de responsabilidade para a configuração deste dever de indenizar.

Neste caso, havendo uma conduta - comissiva ou omissiva - e um dano, e se entre eles houver uma relação de causa e efeito, um liame causal que ligue a conduta do agente ao dano provocado, sobrevirá o dever de indenizar.

Se já era dispensável a verificação da culpa na responsabilidade civil objetiva, nesta modalidade nenhum outro juízo de valor concernente à conduta do agente ou ao evento em que se verificou a ocorrência do dano será feito, nem mesmo quando restar comprovada a presença de alguma das causas excludentes de responsabilidade.

Para Sergio Cavalieri Filho a teoria do risco integral representa uma “...modalidade extremada da doutrina do risco para justificar o dever de indenizar mesmo nos casos de culpa exclusiva da vitima, fato de terceiro, caso fortuito ou força maior" ${ }^{47}$. O simples fato de se exercer certa atividade será suficiente para surgir o dever de indenizar, tão logo verificado o dano.

Explica Annelise Monteiro Steigleder que é a modalidade de responsabilidade civil através da qual “...todo e qualquer risco conexo ao empreendimento deverá ser integralmente internalizado pelo processo

\footnotetext{
${ }^{47}$ CAVALIERI FILHO, Sergio. Programa de responsabilidade civil. 5. ed. rev. aum. atual. São Paulo: Malheiros, 2004. p. 240-241.
} 
produtivo, devendo o responsável reparar quaisquer danos que tenham conexão com sua atividade" ${ }^{48}$. A justificativa para adoção deste modelo encontra-se nos riscos impingidos ao patrimônio ambiental por determinada atividade, os quais serão totalmente assumidos por aquele que a exerce, sendo irrelevante a forma através da qual ocorreu o dano.

Para Édis Milaré este modelo de responsabilização civil é fundado na teoria do risco inerente a certa atividade, objetivando "fazer recair sobre o autor do dano o ônus decorrente dos custos sociais de sua atividade ${ }^{\text {"49 }}$.

De acordo com o autor, além de prescindibilidade de culpa e da irrelevância da licitude da atividade - que será analisada posteriormente, a adoção desta modalidade de responsabilidade civil será a inaplicabilidade do caso fortuito e da força maior como exonerativas ${ }^{50}$.

\subsection{Risco integral e a tutela do meio ambiente}

Já vimos que a responsabilidade civil por danos ambientais deve atender, necessariamente, a outros objetivos que o modelo tradicional de responsabilidade não procura satisfazer, como é o caso de seu caráter preventivo. Ante a dificuldade, e muitas vezes impossibilidade, de restabelecer o status quo do bem aqui tutelado, não basta para justificar o dever de indenizar, muitas vezes, a simples reparação daquela lesão específica.

Somando-se a estes princípios, destacamos que o meio ambiente ecologicamente equilibrado é um direito de todos, como bem explicitado na Constituição da República, em seu artigo 225. Quaisquer ações, ou omissões, que venham a prejudicá-lo estarão lesando o direito, não de um particular apenas, mas de toda a coletividade.

\footnotetext{
${ }^{48}$ STEIGLEDER, Annelise Monteiro. Responsabilidade civil ambiental: as dimensões do dano ambiental no direito brasileiro. Porto Alegre: Livraria do Advogado, 2004. p. 198.

${ }^{49}$ MILARÉ, Édis. Direito do ambiente. 2. ed. rev. aum. atual. São Paulo: Revista dos Tribunais, 2001. p. 429.
} 
Nesta linha de raciocínio podemos afirmar a necessidade de se criar um arcabouço jurídico amplamente eficiente, não deixando qualquer brecha que possa impossibilitar a indenização de uma ofensa a este bem público. Álvaro Mirra atenta para esta necessidade:

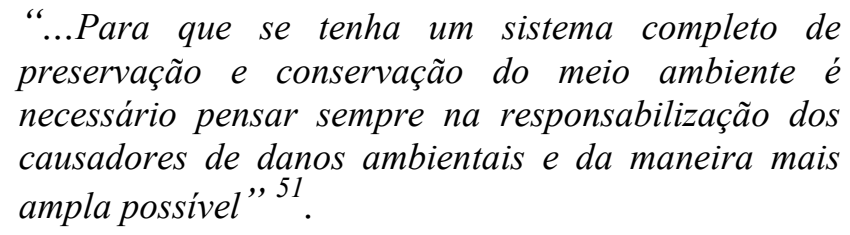
preservação e conservação do meio ambiente é necessário pensar sempre na responsabilização dos causadores de danos ambientais e da maneira mais ampla possivel" 51 .

Tal preceito virou realidade com a entrada em vigor da Lei de Política Nacional do Meio Ambiente, em agosto de 1981 e, posteriormente, com a promulgação da Constituição da República, em 1988.

A questão central que se debate é sobre a adequação da teoria do risco integral aos danos causados ao meio ambiente. Por ser uma modalidade extremamente gravosa, salienta Sergio Cavalieri, apenas foi adotada em nosso ordenamento em situações excepcionais ${ }^{52}$.

E a proteção ambiental representa, de acordo com o autor, uma dessas causas excepcionais, justificando seu entendimento no fato de que seria impossível vislumbrar a incidência da Lei $\mathrm{n}^{\circ}$ 6.938/81, na maioria dos casos de poluição ambiental, caso se pudesse invocar o caso fortuito e força maior como causa excludentes de responsabilidade $\operatorname{civil}^{53}$.

Pois bem, a Lei $n^{\circ} 6.938 / 81$ estabeleceu a responsabilidade objetiva do causador do dano ambiental ao dispor que o poluidor é obrigado a indenizar ou reparar os danos causados ao meio ambiente independentemente

\footnotetext{
${ }^{50}$ Ibid. p. 434.

${ }^{51}$ MIRRA, Álvaro Luiz Valery. Princípios fundamentais do direito ambiental. Revista de Direito Ambiental, São Paulo, n. 2, p. 50-66. 1996. p. 62.

${ }^{52}$ CAVALIERI FILHO, Sergio. Programa de responsabilidade civil. 5. ed. rev. aum. atual. São Paulo: Malheiros, 2004. p. 148.

${ }^{53}$ Ibid. p. 153.
} 
da existência de culpa ${ }^{54}$. No mesmo sentido a Constituição de 1988 dispõe que as condutas lesivas sujeitarão os infratores à obrigação de reparar os danos causados $^{55}$.

Assentado está, portanto, que nosso legislador adotou a responsabilidade objetiva para as hipóteses de danos ocasionados ao meio ambiente, sendo irrelevante a discussão acerca da conduta do agente. Uma das conseqüências da adoção deste sistema será a inaplicabilidade de quaisquer excludentes de responsabilidade ${ }^{56}$.

No mesmo sentido, Antônio Herman Benjamin afirma que o Direito ambiental em nosso país não admite como excludente de responsabilidade o fato de terceiro, a culpa concorrente da vítima, nem caso fortuito e força maior. Defende o autor que:

"...se o evento ocorreu no curso ou em razão de atividade potencialmente degradadora, incumbe ao responsável por ela reparar eventuais danos causados, ressalvada sempre a hipótese de ação regressiva" 57.

Annelise Monteiro Steigleder faz uma importante ressalva para o texto contido na Lei $\mathrm{n}^{\mathrm{o}}$ 6.938/81, no qual não se restringe a responsabilidade civil à periculosidade da atividade, mas sim ao dano ambiental provocado. Para se justificar a adoção desta modalidade agravada de

\footnotetext{
${ }^{54}$ O Art. $14, \S 1^{\circ}$ da Lei 6.938/81 assim dispõe: "Sem obstar a aplicação das penalidades previstas neste artigo, é o poluidor obrigado, independentemente da existência de culpa, a indenizar ou reparar os danos causados ao meio ambiente e a terceiros, afetados por sua atividade. O Ministério Público da União e dos Estados terá legitimidade para propor ação de responsabilidade civil e criminal, por danos causados ao meio ambiente".

${ }^{55}$ Assim, dispõe o Art. 225, $\S 3^{\circ}$ da Constituição Federal: “...As condutas e atividades consideradas lesivas ao meio ambiente sujeitarão os infratores, pessoas físicas ou jurídicas, a sanções penais e administrativas, independentemente da obrigação de reparar os danos causados".

${ }^{56}$ JÚNIOR, Nelson Nery; NERY, Rosa Maria B. B. de Andrade. Responsabilidade civil, meioambiente e ação coletiva ambiental. In: DANO ambiental: prevenção, recuperação e repressão. São Paulo: Revista dos Tribunais, 1993. p. 280.

${ }^{57}$ BENJAMIN, Antonio Herman V. Responsabilidade civil pelo dano ambiental. Revista de Direito Ambiental, São Paulo, n. 9, p. 5-52, jan/mar. 1998. p. 8.
} 
responsabilização, não será levado em conta o perigo que representa a atividade, e sim o dano ocasionado ao meio ambiente ${ }^{58}$.

O objetivo da Lei não é coibir determinadas atividades, necessárias ao desenvolvimento do país, mas sim abarcar todo e qualquer dano causado ao meio ambiente, impedindo qualquer possibilidade de que este não seja totalmente reparado quando lesado, mesmo quando ocasionado por atividade que teoricamente não apresentava potencial poluidor.

Neste sentido, uma fundamental decisão para a adoção do modelo de responsabilidade civil aqui estudado foi prolatada pelos Ministros da Primeira Turma do Superior Tribunal de Justiça, que decidiram pela aplicação da teoria do risco integral, como se verifica a partir do trecho do acórdão abaixo transcrito:

“3. O poluidor, por seu turno, com base na mesma legislação, art. 14 - "sem obstar a aplicação das penalidades administrativas” é obrigado, "independentemente da existência de culpa”, a indenizar ou reparar os danos causados ao meio ambiente e a terceiros, “afetados por sua atividade".

4. Depreende-se do texto legal do texto legal a sua responsabilidade pelo risco integral..."59

Devemos Frisar a importância desta recente decisão, uma vez que foi a primeira emanada por esta Corte a confirmar matéria amplamente

\footnotetext{
${ }^{58}$ STEIGLEDER, Annelise Monteiro. Responsabilidade civil ambiental: as dimensões do dano ambiental no direito brasileiro. Porto Alegre: Livraria do Advogado, 2004. p. 198.

${ }^{59}$ BRASIL. Superior Tribunal de Justiça. REep $n^{\circ} 442.586$. Recorrentes: Rede Bandeirantes de Postos de Serviços Ltda. Recorrido: Companhia de Tecnologia de Saneamento Ambiental - CETESB. Rel: Ministro Luiz Fux, Brasília, 26 nov. 2002.
} 
defendida em sede doutrinária, no que diz respeito à aplicação da teoria do risco integral nas hipóteses de danos causados ao meio ambiente.

Muitos autores afirmam que as excludentes aqui assinaladas estariam relacionadas ao nexo causal. Para eles o caso fortuito, a força maior, a culpa exclusiva da vítima e o fato de terceiro seriam excludentes de nexo causal $^{60}$.

Defendem estes autores, por conseqüência lógica, que na teoria do risco integral não é necessário o nexo causal, apenas sendo primordial a constatação de um dano e uma conduta do agente. Adalberto Pasqualotto assinala que o caso fortuito e a força maior afastariam o nexo de causalidade, pois o dano não se relacionaria a qualquer ação ou omissão do agente.

Para o autor, a força maior apenas seria admitida como excludente nas hipóteses de acidente nuclear, se restasse configurada a existência de conflito armado, hostilidades, guerra civil, insurreição ou excepcional fato da natureza, de acordo com o que está disposto na Lei $\mathrm{n}^{\mathrm{o}}$ $6.453 / 1977^{61}$. De forma diversa, a culpa exclusiva da vítima, o dolo de terceiro e o caso fortuito não representam exonerativas de responsabilidade pois, nas hipóteses de dano, de natureza difusa, toda a coletividade é prejudicada, e o risco é inerente à atividade, cabendo ação regressiva ${ }^{62}$.

Apesar de seguir esta linha de raciocínio, defendendo que as excludentes de responsabilidade afastam o nexo de causalidade, Sergio Cavalieri afirma que essas causas exonerativas incidem em nosso ordenamento

\footnotetext{
${ }^{60}$ Édis Milaré distingue a força maior do caso fortuito afirmando que o primeiro diz respeito a um evento da natureza, não relacionado com a atividade humana, como a ocorrência de um raio ou precipitação pluviométrica, e o segundo estaria relacionado à obra do acaso, como a explosão de um reator nuclear (MILARÉ, Édis. Direito do ambiente. 2. ed. rev. aum. atual. São Paulo: Revista dos Tribunais, 2001. p. 116).

${ }^{61}$ Lei $\mathrm{n}^{\mathrm{o}} 6.453 / 77$, art. $8^{\mathrm{o}}$ : "O operador não responde pela reparação do dano resultante de acidente nuclear causado diretamente por conflito armado, hostilidades, guerra civil, insurreição ou excepcional fato da natureza".

${ }^{62}$ PASQUALOTTO, Adalberto. Responsabilidade civil por dano ambiental: considerações de ordem material e processual. In: DANO ambiental: prevenção, reparação e repressão. São Paulo: Revista dos Tribunais, 1993. p. 456.
} 
jurídico, uma vez que o dispositivo legal acima referido não teria sido recepcionado pela Constituição Federal de 1988, senão vejamos:

\begin{abstract}
"Ainda na Constituição, no art. 21, XXIII, "c", vamos encontrar mais uma hipótese de responsabilidade objetiva, que tem lugar no caso de acidentes nucleares, de responsabilidade da União. Dado a enormidade dos riscos decorrentes da exploração da atividade nuclear, também aqui foi adotada a teoria do risco integral. O art. $8^{\circ} \mathrm{da}$ Lei $n^{\circ}$ 6.453/1977 exclui a responsabilidade do operador por dano resultante de acidente nuclear causado diretamente por conflito armado, hostilidades, guerra civil, insurreição ou excepcional fato da natureza. $A$ base jurídica da responsabilidade do explorador da atividade nuclear, entretanto, passou a ser a Constituição, a partir de 1988, e esta, em seu art. 21, XXIII, "c", não abre exceção alguma, pelo que entendemos não mais estarem em vigor as causas exonerativas previstas na lei infraconstitucional ${ }^{163}$.
\end{abstract}

Com a promulgação da Carta Magna, o legislador definiu a competência da União para exploração dos serviços e instalações nucleares de qualquer natureza. Não deixou margem a qualquer hipótese de causa exonerativa de responsabilidade, pelo que se entendeu aplicar-se, também aqui, a teoria do risco integral nas hipóteses de danos causados em decorrência de atividade nuclear, revogado-se o dispositivo contido na Lei $\mathrm{n}^{\mathrm{o}} 6.453 / 77^{64}$.

Cumpre-nos agora identificar a forma como se dará este dever de indenizar, analisando a fundamentação teórica da responsabilidade objetiva aplicável ao dano ambiental, os pressupostos de responsabilização, como o nexo de causalidade e a conduta, bem como os agentes ativos envolvidos.

\footnotetext{
${ }^{63}$ CAVALIERI FILHO, Sergio. Programa de responsabilidade civil. 5. ed. rev. aum. atual. São Paulo: Malheiros, 2004. p. 154.

${ }^{64}$ Art 21, inciso XXIII, da Constituição Federal dispõe sobre a competência da União no que se refere à atividade nuclear: "explorar serviços e instalações nucleares de qualquer natureza e exercer monopólio estatal sobre a pesquisa, a lavra, o enriquecimento e o reprocessamento, a industrialização e o comércio de minérios nucleares e seus derivados, atendidos os seguintes princípios e condições: (...) c) a responsabilidade civil por danos nucleares independe da existência de culpa".
} 


\section{Responsabilidade Civil Ambiental}

\subsection{Nexo de causalidade}

O nexo de causalidade é o elo que liga a conduta do agente ao dano por ele provocado, é o liame, o vínculo necessário à verificação da relação de causa e efeito existente entre determinada ação - ou omissão - e o dano por ela produzido. Afirma Sergio Cavalieri Filho ser o elemento referencial através do qual "poderemos concluir quem foi o causador do dano" ${ }^{, 65}$.

Para Édis Milaré a constatação do nexo causal é imprescindível, e consiste na "relação de causa e efeito entre a atividade do agente e o dano dela advindo".

De acordo com o autor, o problema situa-se na comprovação do nexo causal, muitas vezes de difícil aferição, seja pela pluralidade de causas, cada qual contribuindo para uma parcela do dano, seja pelo anonimato do agente, ou mesmo pelo longo lapso temporal transcorrido entre a atividade poluidora e os seus efeitos nocivos verificados no meio ambiente ${ }^{66}$.

Sobre o nexo de causalidade nas hipóteses de atividades potencialmente poluidoras, Annelise Monteiro Steigleder afirma que " $o$ explorador da atividade econômica coloca-se na posição de garantidor da preservação ambiental e os danos que digam respeito à atividade estarão sempre vinculados a ela".

\footnotetext{
${ }^{65}$ CAVALIERI FILHO, Sergio. Programa de responsabilidade civil. 5. ed. rev. aum. atual. São Paulo: Malheiros, 2004. p. 66.

${ }^{66}$ MILARÉ, Édis. Direito do ambiente. 2. ed. rev. aum. atual. São Paulo: Revista dos Tribunais, 2001. p. 116.
} 
Por ser objetiva a responsabilidade, sustenta a autora que os riscos inerentes à atividade substituirão qualquer juízo de valor acerca da conduta do poluidor ${ }^{67}$.

No caso do dano ambiental, muitas dificuldades surgem na verificação do liame causal existente entre uma determinada atividade e os danos por ela ocasionados, e isto se dá, muitas vezes, em razão da multiplicidade de agentes causadores como, por exemplo, na hipótese de poluição de um rio por lançamentos de material químico por um complexo industrial.

Sobre esta multiplicidade de causas de degradação ambiental, ensina Antônio Herman Benjamin que o dano ambiental "pode ser resultado de várias causas concorrentes, simultâneas ou sucessivas, dificilmente tendo uma única e linear fonte ${ }^{, 68}$.

Sustenta ainda o autor a inexistência, em nosso ordenamento pátrio, de qualquer distinção entre "causa principal, causa acessória e concausa" $"$.

É o caso em que resta muito complicado estabelecer qual atividade gerou aquele dano, e não só isso, mas também qual seria a proporção de responsabilidade de cada agente industrial. Sendo certo que houve um dano, a dificuldade de se apurar quem o ocasionou, bem como em que quantidade contribuiu não pode servir de alicerce para a impunidade.

E como se não bastasse esta dificuldade apontada, não se pode ignorar aquelas atividades que, individualizadas, não serão capazes de ocasionar nenhum dano, mas, quando entram em contato com outros agentes, configura-se sua capacidade poluidora, antes inexistente ${ }^{70}$. No mesmo sentido,

\footnotetext{
${ }^{67}$ STEIGLEDER, Annelise Monteiro. Responsabilidade civil ambiental: as dimensões do dano ambiental no direito brasileiro. Porto Alegre: Livraria do Advogado, 2004. p. 197.

${ }^{68}$ BENJAMIN, Antonio Herman V. Responsabilidade civil pelo dano ambiental. Revista de Direito Ambiental, São Paulo, n. 9, p. 5-52, jan/mar. 1998. p. 44.

${ }^{69}$ Ibid. p. 45.

${ }^{70}$ Ibid. p. 44.
} 
Édis Milaré assinala a existência de lesões que, isoladas, não causam dano significativo, mas, em um determinado contexto, somada à outra atividade, alarga seu potencial poluidor ${ }^{71}$.

Para solucionar este conflito, afirma-se que a simples existência do risco é suficiente para ensejar a responsabilidade de determinada atividade. Assim que configurado o dano:

"havendo mais de uma causa provável do dano, todas serão reputadas suficientes para produzi-lo, não se distinguindo entre causa principal e causas secundárias, pelo que a própria existência da atividade é reputada causa do evento lesivo"72.

Todos aqueles que de alguma forma concorrerem para a configuração do dano serão reputados responsáveis, ou seja, nas hipóteses onde subsistir uma multiplicidade de agentes, serão todos solidariamente responsabilizados, cabendo a eles demonstrar que, não obstante tratar-se de uma atividade potencialmente poluidora, sua conduta em nada contribuiu para a configuração do dano.

Para Jorge Alex Nunes Athias, prevalecerá entre os agentes poluidores o vínculo de solidariedade, pois em muitos casos será impossível auferir a contribuição de cada um para a ocorrência do dano, não podendo, por isto, restar o meio ambiente indene ${ }^{73}$.

Indo um pouco mais além do estabelecimento da responsabilidade solidária entre todos os agentes, como forma de superação da dificuldade de verificação do nexo de causalidade, Antônio Herman Benjamin

\footnotetext{
${ }^{71}$ MILARÉ, Édis. Direito do ambiente. 2. ed. rev. aum. atual. São Paulo: Revista dos Tribunais, 2001. p. 430.

72 STEIGLEDER, Annelise Monteiro. Responsabilidade civil ambiental: as dimensões do dano ambiental no direito brasileiro. Porto Alegre: Livraria do Advogado, 2004. p. 201.

${ }^{73}$ ATHIAS, Jorge Alex Nunes. Responsabilidade civil e meio ambiente: breve panorama do direito brasileiro. In: Dano ambiental: prevenção, recuperação e repressão. São Paulo: Revista dos Tribunais, 1993. p. 244.
} 
defende sua facilitação através da presunção de causalidade, da inversão mais ampla do ônus da prova e da adoção de responsabilidade civil alternativa ${ }^{74}$.

Sobre os dois primeiros entendemos que um decorrerá necessariamente do outro, posto que, presumindo-se o nexo de causalidade quando da ocorrência de um dano ao meio ambiente, estar-se-á impondo ao poluidor - presumido - o ônus de comprovar que sua atividade não guarda relação alguma de causa e efeito com o dano verificado.

Outros autores afirmarão não ser necessária uma via muito extensa para a verificação do nexo causal em matéria ambiental. Assim, pelo que podemos extrair dos ensinamentos de Nelson Néri Júnior e Rosa Maria Nery, a prática de atividade potencialmente poluidora causadora de dano ao meio ambiente enseja responsabilização, sendo irrelevante se a atividade não foi causadora do dano específico, posto que apenas será necessário verificar a relação de causa e efeito entre as diversas condutas e o dano provocado.

De acordo com o autor, em sede de responsabilidade objetiva, para a demonstração do nexo causal basta a demonstração de um dano para o qual o risco da atividade exerce uma influência causal definitiva ${ }^{75}$. É o caso de se estabelecer se o dano persistiria mesmo se não existisse aquela atividade, hipótese na qual não restará configurado o liame causal.

Nesta linha aponta Adalberto Pasqualotto, para quem não há que se falar em nexo de causalidade, mas sim em condição propícia à ocorrência do evento danoso. De acordo com o autor "a ação, da qual a teoria da culpa faz depender a responsabilidade pelo resultado, é substituida pela assunção do risco em provocá-lo" ${ }^{, 76}$. Defende ainda a desconsideração do nexo

\footnotetext{
${ }^{74}$ BENJAMIN, Antonio Herman V. Responsabilidade civil pelo dano ambiental. Revista de Direito Ambiental, São Paulo, n. 9, p. 5-52, jan/mar. 1998. p. 46.

75 JÚNIOR, Nelson Nery; NERY, Rosa Maria B. B. de Andrade. Responsabilidade civil, meioambiente e ação coletiva ambiental. In: Dano ambiental: prevenção, recuperação e repressão. São Paulo: Revista dos Tribunais, 1993. p. 281-282.

${ }^{76}$ PASQUALOTTO, Adalberto. Responsabilidade civil por dano ambiental: considerações de ordem material e processual. In: DANO ambiental: prevenção, reparação e repressão. São Paulo: Revista dos Tribunais, 1993. p. 454.
} 
de causalidade em casos extremos, como acidente nuclear, mas não nas hipóteses de menor gravidade ${ }^{77}$.

O nexo causal passa a ser uma simples averiguação acerca do potencial poluidor de uma atividade, se esta criou as condições através das quais ocorreu o dano, hipótese na qual, pelo simples fato de assumir quaisquer riscos relativos ao empreendimento, restará configurada a ligação entre a atividade e este dano. Embasando este entendimento, afirma Annelise Steigleder:

"...na teoria do risco integral, que se vale da teoria da equivalência das condições para aferição do liame causal, basta que o dano possa estar vinculado à existência do fator de risco, o qual é reputado causa do dano, pelo que qualquer evento condicionante é equiparado à causa do prejuizo, sem a exigência de que este seja a conseqüência necessária, direta e imediata do evento" ${ }^{, 78}$.

Defende a autora que o nexo causal será presumido, e só não responderá pelo dano o agente caso este consiga comprovar que o dano teria ocorrido independentemente da sua conduta ${ }^{79}$. Aqui mais uma vez identifica-se a inversão do ônus da prova, pois certo será que, nesta hipótese, o agente presumido como ofensor terá de fazer uma prova negativa de sua ação - ou omissão - para que se desconstitua o dever de indenizar.

Em matéria ambiental, não há qualquer juízo de valor a incidir sobre a conduta do ofensor, não importando, para restar configurado o nexo de causalidade, que aquela atividade poluidora tenha respeitado os exatos padrões técnicos e normativos estabelecidos pelos órgãos reguladores e fiscalizadores.

\subsection{Licitude ou ilicitude da atividade}

\footnotetext{
${ }^{77}$ Ibid. p. 455.

${ }^{78}$ STEIGLEDER, Annelise Monteiro. Responsabilidade civil ambiental: as dimensões do dano ambiental no direito brasileiro. Porto Alegre: Livraria do Advogado, 2004. p. 202.
} 
Outra questão importante a ser analisada diz respeito à licitude da atividade poluidora. Questiona-se a possibilidade de isenção de responsabilidade de uma determinada atividade, quando da ocorrência de dano ao meio ambiente, nas hipóteses de total respeito às normas e padrões destinados à proteção ambiental, devidamente autorizada pelos órgãos competentes.

Para Édis Milaré uma das conseqüências da adoção da responsabilidade civil objetiva será a irrelevância da conduta lícita do agente causador do dano ao meio ambiente. Não basta, é irrelevante a alegação de que a atividade é lícita, exercida de acordo com padrões estabelecidos pela autoridade administrativa.

Sustenta o autor que "a responsabilidade civil pelo dano ambiental não é típica, independe de ofensa a standard legal ou regulamentar específico, já que não tem o poder público, em nosso caso, o direito de consentir na agressão à saúde da população através do controle exercido pelos seus órgãos". A potencialidade de dano da atividade, e não sua legalidade, é que deverá ser o objeto de análise para verificação do dever de indenizar ${ }^{80}$.

A potencialidade danosa de certa atividade é a justificativa para a imposição do dever de indenizar quando se verificar efetivado o prejuízo ao meio ambiente, não se chega a valorar, segundo o autor, se aquela atividade é lícita ou ilícita.

Além disso, admitir a licitude como uma forma de elidir o causador de um dano do dever de indenizá-lo implicará afirmar que o poder público tem a discricionariedade para determinar a possibilidade do responsável por certa atividade de degradar o meio ambiente.

\footnotetext{
${ }^{79}$ Ibid. p. 204.
} 
Paulo Affonso Leme Machado repudia este entendimento, sustentando a impossibilidade de a administração pública, "intencionalmente, desconsiderar os valores ambientais constitucionais", os quais, acentua o autor, são indisponíveis ${ }^{81}$.

Mais do que isso, além de a licitude não representar defesa contra uma agressão causada ao meio ambiente, Jorge Alex Nunes Athias afirma que a autorização, o licenciamento da atividade pelo poder público trará para este a obrigação de indenizar em solidariedade ao agente causador do dano, ainda que de acordo com a legislação vigente. Afirma o autor, taxativamente, que "a licitude da atividade não é excludente" $"$.

Adalberto Pasqualotto e Francisco J. M. Sampaio seguem a mesma linha no que diz respeito à licitude da atividade, o primeiro defende que esta não é causa e excludente de responsabilidade, nem os fatores poluidores preexistentes $^{83}$.

Já o segundo autor afirma ser suficiente, "para tornar obrigatória a reparação a ocorrência do dano, a existência de uma conduta comissiva ou omissiva que o tenha provocado, a comprovação da autoria do fato que a ele deu origem e o nexo da causalidade entre ambos, não importando para este fim que a atividade degradadora seja, ou não, lícita e licenciada pelos órgãos competentes" $"$.

Quando falamos sobre responsabilidade civil no início do presente estudo afirmamos que um dos pressupostos seria o ato ilícito. Para

\footnotetext{
${ }^{80}$ MILARÉ, Édis. Direito do ambiente. 2. ed. rev. aum. atual. São Paulo: Revista dos Tribunais, 2001. p. $432-433$.

${ }^{81}$ MACHADO, Paulo Affonso Leme. Direito ambiental brasileiro. 12 ed. São Paulo: Malheiros Editores, 2004. p. 342.

${ }^{82}$ ATHIAS, Jorge Alex Nunes. Responsabilidade civil e meio ambiente: breve panorama do direito brasileiro. In: Dano ambiental: prevenção, recuperação e repressão. São Paulo: Revista dos Tribunais, 1993. p. 247.

${ }^{83}$ PASQUALOTTO, Adalberto. Responsabilidade civil por dano ambiental: considerações de ordem material e processual. In: DANO ambiental: prevenção, reparação e repressão. São Paulo: Revista dos Tribunais, 1993. p. 458.

${ }^{84}$ SAMPAIO, Francisco J. Marques. Meio ambiente no direito brasileiro atual. Curitiba: Editora Juruá, 1993. p. 75.
} 
que não haja equívocos quanto a uma suposta contradição, explicamos a diferença entre a conduta ilícita que lá mencionamos e a licitude da atividade.

De fato, majoritariamente entende nossa doutrina não ser necessário, para a configuração do dever de indenizar um dano causado ao meio ambiente, que a atividade seja ilícita. Esperamos ter demonstrado que persistirá a responsabilização civil sobre a atividade, mesmo sendo esta lícita e em consonância com os padrões técnicos estabelecidos pelos órgãos competentes.

A ilicitude se afigura não no estabelecimento ou desenvolvimento da atividade, mas sim no ato de poluir, que representa uma ofensa a um bem juridicamente tutelado, protegido o meio ambiente.

A ilicitude, no definir de Sergio Cavalieri Filho, configurar-seá quando da violação de um dever preexistente ${ }^{85}$. Pela definição contida no Código Civil podemos afirmar que o ato ilícito será imputado a alguém quando este causar um dano a outrem, através de uma ação ou omissão voluntária, negligência ou imprudência ${ }^{86}$. Ou ainda, quando o titular de um direito exceder os limites impostos pelo seu fim econômico ou social, pela boa-fé e pelos bons costumes ${ }^{87}$.

Afirma ainda o autor que o ato ilícito, em sentido amplo, "indica apenas a ilicitude do ato, a conduta humana antijurídica, contrária ao Direito, sem qualquer referência ao elemento subjetivo ou psicológico" ${ }^{\text {} 88}$. A poluição, além da agressão imediata e direta ao meio ambiente ecologicamente

\footnotetext{
${ }^{85}$ CAVALIERI FILHO, Sergio. Programa de responsabilidade civil. 5. ed. rev. aum. atual. São Paulo: Malheiros, 2004. p. 30.

${ }^{86}$ Art. 186 do Código Civil: "Aquele que, por ação ou omissão voluntária, negligência ou imprudência, violar direito e causar dano a outrem, ainda que exclusivamente moral, comete ato ilícito."

${ }^{87}$ Art. 187 do Código Civil: "Também, comete ato ilícito o titular de um direito que, ao exercê-lo, excede manifestamente os limites impostos pelo seu fim econômico ou social, pela boa-fé ou pelos bons costumes."

${ }^{88}$ CAVALIERI FILHO, Sergio. Programa de responsabilidade civil. 5. ed. rev. aum. atual. São Paulo: Malheiros, 2004. p. 32.
} 
equilibrado, fere, não só o ordenamento jurídico, como também o direito de todos ao meio ambiente ecologicamente equilibrado.

Certo é que a Constituição Federal estabeleceu que todos têm direito ao meio ambiente equilibrado. Aquele que quebrar este equilíbrio romperá a barreira juridicamente permitida, independente de quaisquer certificados e licenças para funcionamento que determinada atividade possa possuir. Sua atividade é lícita, mas o resultado por ela alcançado é ilícito, pois a ninguém é conferida a prerrogativa de poluir.

\subsection{Os agentes responsáveis}

É amplo o alcance dado pela Lei n ${ }^{\circ} 6.938 / 1981$ aos agentes responsáveis por danos causados ao meio ambiente, pois no art. $3^{\circ}$, inciso IV, está definido o poluidor como qualquer pessoa, física ou jurídica, de direito público ou privado, responsável direta ou indiretamente por atividade causadora de degradação ambiental.

Primeiramente, utilizamos os ensinamentos de Antônio Herman Benjamin, para quem não há dúvida de que independe ser o ente poluidor público ou privado, pois tanto um como o outro será passível de responsabilização ${ }^{89}$.

Porém, ressaltamos interessante opinião de Édis Milaré sobre a responsabilidade do ente estatal. Neste caso, por ilação lógica pode-se afirmar que o próprio povo arcará com o custo da reparação, devendo, pois, em regra, ser acionado prioritariamente aquele particular que solidariamente é responsável, e só o Estado quando este for o causador direto ${ }^{90}$.

\footnotetext{
${ }^{89}$ BENJAMIN, Antonio Herman V. Responsabilidade civil pelo dano ambiental. Revista de Direito Ambiental, São Paulo, n. 9, p. 5-52, jan/mar. 1998. p. 37.

${ }^{90}$ MILARÉ, Édis. Direito do ambiente. 2. ed. rev. aum. atual. São Paulo: Revista dos Tribunais, 2001. p. 437.
} 
Sentencia o autor que o titular do dever de indenizar é o empreendedor, aquele que aufere lucro da atividade danosa, existindo o vínculo de solidariedade quando da pluralidade de agentes causadores ${ }^{91}$.

Mas não se resume ao empreendedor, ainda na visão do autor, pois para ele o Estado também responde pelos danos causados ao meio ambiente, e não só quando o ente público é o responsável direto pelo evento danoso, como também no caso de omissão na guarda do meio ambiente, podendo ser responsabilizado solidariamente pelos danos causados por terceiros.

Destaque-se a regra geral, contida no art. $37, \S 6^{\circ}$, da Constituição Federal, de responsabilização objetiva do Estado - pessoas jurídicas de direito público e as de direito privado prestadoras de serviços públicos - quando do dano perpetrados a terceiros ${ }^{92}$.

De acordo com Adalberto Pasqualotto, embasado no preceito constitucional acima referido, a administração pública responde objetivamente pelos danos causados a terceiros, aplicando-se a regra também nos casos de omissão do ente estatal caso este seja a única causa do evento danoso. Contudo, defende que, quando à omissão do ente público somar-se ato comissivo de um causador direto, deverá ser comprovada a culpa do Estado ${ }^{93}$.

Paulo Affonso Leme Machado sustenta que a responsabilização solidária do Estado se justificaria para compeli-lo a ser "prudente e cuidadoso no vigiar, orientar e ordenar a saúde ambiental nos

\footnotetext{
${ }^{91}$ MILARÉ, Édis. Direito do ambiente. 2. ed. rev. aum. atual. São Paulo: Revista dos Tribunais, 2001. p. 436.

${ }_{92}$ Assim estabelece o Art. 37, § $6^{\circ}$ da Constituição Federal: “As pessoas jurídicas de direito público e as de direito privado prestadoras de serviços públicos responderão pelos danos que seus agentes, nessa qualidade, causarem a terceiros, assegurado o direito de regresso contra o responsável nos casos de dolo ou culpa".

${ }^{93}$ PASQUALOTTO, Adalberto. Responsabilidade civil por dano ambiental: considerações de ordem material e processual. In: DANO ambiental: prevenção, reparação e repressão. São Paulo: Revista dos Tribunais, 1993. p. 452.
} 
casos em que haja prejuízo para as pessoas, para a propriedade ou para os recursos naturais mesmo com a observância dos padrões oficiais" 94.

Outro possível agente a ser analisado é o profissional responsável pelos estudos necessários à implantação de determinada atividade potencialmente poluidora.

A resolução $n^{0}$ 237/1997 do CONAMA estabelece a obrigatoriedade de realização de estudos de impacto ambiental, necessários ao licenciamento de atividades potencialmente poluidoras que utilizam recursos ambientais, que deverão ser realizados por profissionais legalmente habilitados 95 .

O parágrafo único do art. 11 desta resolução aponta para a responsabilidade dos profissionais que subscrevem estes estudos, assim como do empreendedor, pelas informações apresentadas.

Contudo, Édis Milaré não reconhece solidariedade a estes profissionais, pois teria que ser provado sua negligência, imprudência ou imperícia, o que não cabe em sede de responsabilidade objetiva, e justifica: “o empreendedor é quem recolhe os beneficios de sua atividade, cabendo-lhe, de conseqüência, o dever ressarcitório, pela simples verificação do nexo causal" 96 .

Neste caso devemos salientar que, responsabilizado o empreendedor pelos danos causados, a ele caberia, pela via regressiva, acionar o profissional responsável pelo estudo apresentado, desde que conseguisse comprovar sua culpa no evento danoso. No mesmo sentido aponta Adalberto

\footnotetext{
${ }^{94}$ MACHADO, Paulo Affonso Leme. Direito ambiental brasileiro. 12 ed. São Paulo: Malheiros Editores, 2004. p. 332.

${ }^{95}$ Resolução 237/97 - CONAMA, Art. 11: “Os estudos necessários ao processo de licenciamento deverão ser realizados por profissionais legalmente habilitados, às expensas do empreendedor".

${ }^{96}$ MILARÉ, Édis. Direito do ambiente. 2. ed. rev. aum. atual. São Paulo: Revista dos Tribunais, 2001. p. 438.
} 
Pasqualotto, para quem a responsabilidade deste profissional será subjetiva e regressiva ${ }^{97}$.

Mais amplo é o campo de incidência da responsabilidade civil para Antônio Herman Benjamin. De acordo com o autor o termo utilizado no art. $3^{\circ}$, inciso IV da Lei ${ }^{\circ} 6.938$ :

“...inclui aqueles que diretamente causam o dano ambiental (o fazendeiro, o industrial, o madeireiro, $o$ minerador, o especulador), bem como os que indiretamente com ele contribuem, facilitando ou viabilizando a ocorrência do prejuizo (o banco, o órgão publico licenciador, o engenheiro o arquiteto, o incorporador, o corretor, o transportador, para citar alguns personagens)" ${ }^{98}$.

Há, inclusive, precedentes jurisprudenciais que apontam neste sentido, inserindo no leque de responsáveis aqueles que cometem a infração, com ela concorrem ou dela se beneficiam, sendo o poluidor não só aquele que “deflagra o processo degradante (causa imediata) mas também quem mantém a atividade econômica ou social que lhe deu origem (causa mediata)" 99.

Tal amplitude encontra cada vez mais respaldo em nossa doutrina e jurisprudência, principalmente no que diz respeito à figura do poluidor indireto. Paulo de Bessa Antunes afirma que, "além do risco do investimento, as instituições financeiras devem considerar que é crescente a tendência para responsabilizar os agentes financeiros por danos causados pelos mutuários" 100 .

\footnotetext{
${ }^{97}$ PASQUALOTTO, Adalberto. Responsabilidade civil por dano ambiental: considerações de ordem material e processual. In: DANO ambiental: prevenção, reparação e repressão. São Paulo: Revista dos Tribunais, 1993. p. 453.

${ }^{98}$ BENJAMIN, Antonio Herman V. Responsabilidade civil pelo dano ambiental. Revista de Direito Ambiental, São Paulo, n. 9, p. 5-52, jan/mar. 1998. p. 37.

${ }^{99}$ BRASIL. Superior Tribunal de Justiça. REep $n^{\circ}$ 442.586. Recorrentes: Rede Bandeirantes de Postos de Serviços Ltda. Recorrido: Companhia de Tecnologia de Saneamento Ambiental - CETESB. Rel: Ministro Luiz Fux, Brasília, 26 nov. 2002.

${ }^{100}$ ANTUNES, Paulo de Bessa. Direito ambiental. 7. ed. Rio de Janeiro: Lúmen Juris, 2004. p. 239.
} 


\subsection{A solidariedade entre os diversos agentes causadores}

Analisados os agentes responsáveis pelo dano ambiental, devemos verificar os casos nos quais não apenas uma é sua fonte causadora. Hipóteses há em que diversas são as fontes poluidoras e o princípio da solidariedade, por sua importância em matéria ambiental, não pode deixar de ser observado.

A solidariedade, como regra geral, decorre em nosso ordenamento jurídico de expressa previsão legal contida no art. 942 do Código Civil, que estabelece que todos os responsáveis pelo evento danoso responderão solidariamente pela reparação ${ }^{101}$.

Da mesma forma defende-se a solidariedade entre todos aqueles que participaram para a ocorrência do dano ambiental. Nos moldes do que foi traçado anteriormente no que concerne ao nexo de causalidade, verificando-se estar presente este pressuposto de responsabilidade, subsistirá o dever de reparar solidariamente.

Sustenta Annelise Monteiro Steigleder que a solidariedade incidirá ainda quando não se puder estabelecer, com precisão, a parcela de contribuição de cada um dos agentes na ocorrência do evento danoso ${ }^{102}$.

A justificativa para a adoção da solidariedade específica neste caso é encontrada na indivisibilidade do dano ambiental, o qual, no entender de Antônio Herman Benjamin, vislumbra-se como "conseqüência de ser o meio ambiente uma unidade infragmentável"103.

\footnotetext{
${ }^{101}$ Assim dispõe o art. 942 do Código Civil: “Os bens do responsável pela ofensa ou violação do direito de outrem ficam sujeitos à reparação do dano causado; e, se a ofensa tiver mais de um autor, todos responderão solidariamente pela reparação".

${ }^{102}$ STEIGLEDER, Annelise Monteiro. Responsabilidade civil ambiental: as dimensões do dano ambiental no direito brasileiro. Porto Alegre: Livraria do Advogado, 2004. p. 217.

${ }^{103}$ BENJAMIN, Antônio Herman V. Apud STEIGLEDER, Annelise Monteiro. Responsabilidade civil ambiental: as dimensões do dano ambiental no direito brasileiro. Porto Alegre: Livraria do Advogado, 2004. p. 217.
} 
Seguindo-se esta linha de raciocínio, aplicar-se-ia à matéria o disposto nos artigos 258 e 259 do Código Civil, que estabelecem a indivisibilidade da obrigação quando também indivisível for seu bem objeto ${ }^{104}$. Assim, da mesma forma, a solidariedade, por ser o dano ambiental indivisível, decorrerá de expressa previsão legal, cabendo a cada um dos responsáveis a responsabilidade pela totalidade da reparação do bem lesado.

A solidariedade em matéria ambiental já foi objeto de análise por parte dos nossos órgãos jurisdicional e, em uma importante decisão, assim entendeu a segunda turma do Superior Tribunal de Justiça:

"para correção do meio ambiente, as empresas são responsáveis solidárias e, no plano interno, entre si, responsabiliza-se cada qual pela participação na conduta danosa”. Seria como “...uma relação externa de unidade entre as rés em frente ao autor da ação civil pública e uma relação fracionária no plano interno" $"$.

Interessante destacar que entre os diversos poluidores, cada qual será responsável por sua parcela de contribuição, o que não ocorre no plano externo, no dever de reparar o bem ambiental lesado, sendo todos responsáveis solidariamente pela reparação total do bem ambiental lesado.

Ressaltou a Ministra Eliana Calmon, relatora do processo, que, nas ações nas quais o objetivo é a preservação do meio ambiente, deriva da própria natureza da ação a solidariedade entre as empresas que se situam em área poluída.

\footnotetext{
${ }^{104}$ Código Civil, art. 258: A obrigação é indivisível quando a prestação tem por objeto uma coisa ou um fato não suscetíveis de divisão, por sua natureza, por motivo de ordem econômica, ou dada a razão determinante do negócio jurídico.

Art. 259: Se havendo dois ou mais devedores, a prestação não for divisível, cada um será obrigado pela dívida toda.

${ }^{105}$ BRASIL. Superior Tribunal de Justiça. REep $n^{\circ}$ 18.567. Recorrente: Solorrico S/A Indústria e Comércio. Recorridos: OIKOS - União dos Defensores da Terra e Ministério Público do Estado de São Paulo. Rel.: Ministra Eliana Calmon, Brasília, 16 junho. 2000.
} 
Em outra importante decisão, que data do ano de 1995, no mesmo sentido decidiu esta Corte no que se refere à solidariedade dos responsáveis, diretos e indiretos, por danos causados ao meio ambiente.

Neste Recurso especial discutia-se a permanência da Fazenda do Estado de São Paulo como litisconsorte passiva necessária, uma vez que esta havia contratado com a empresa diretamente responsável pelo dano ecológico a construção de um presídio ${ }^{106}$.

Restou assentado na referida decisão que a hipótese era de solidariedade, fundamentada, entre outros dispositivos ${ }^{107}$, no art. $3^{\circ}$, inciso IV, da Lei ${ }^{\circ}$ 6.938/1981, que dispõe ser poluidor o responsável direto ou indireto pela degradação ambiental.

Porém uma relevante ressalva se fez necessária, uma vez que, embora admitida a solidariedade entre os diversos agentes causadores do dano ambiental, diretos e indiretos, decidiu aquela Corte por afastar a ocorrência de litisconsórcio passivo necessário, excluindo-se a Fazenda Público do Estado de São Paulo como parte na demanda, salientando que a dívida pode ser exigida por inteiro de qualquer dos ofensores nas hipóteses de responsabilidade solidária.

Neste caso, tratando-se de litisconsórcio passivo facultativo, eventuais direitos existentes entre os agentes solidariamente responsáveis deverão ser reclamados em ação própria, autônoma, por não estarem presentes os requisitos constantes do art. 47 do Código de Processo Civil, quais sejam, a unitariedade e a expressa previsão legal ${ }^{108}$.

\footnotetext{
${ }^{106}$ BRASIL. Superior Tribunal de Justiça. REep $n^{\circ}$ 37.354-9. Recorrente: Freitas Guimarães Projeto e Construção Ltda. Recorrido: Ministério Público do Estado de São Paulo. Rel.: Ministro Antônio de Pádua Ribeiro, Brasília, 30 agosto. 1995.

${ }^{107}$ A decisão mencionada fundamenta a solidariedade, ainda, no art. $14, \S 1^{\mathrm{o}}$ e no art. 18 da Lei $6.938 / 1981$.

${ }^{108}$ Art. 47 do Código de Processo Civil: "Há litisconsórcio necessário, quando, por disposição de lei ou pela natureza da relação jurídica, o juiz tiver de decidir a lide de modo uniforme para todas as partes; caso em que a efícácia da sentença dependerá da citação de todos os litisconsortes no processo".
} 
A solidariedade decorre da necessidade de reparação total do meio ambiente. Se este não fosse o entendimento admitir-se-ia a possibilidade de uma reparação parcial do meio ambiente degradado, nas hipótese em que apenas um dos diversos agentes envolvidos no evento danoso restasse capaz de suportar a carga reparatória da sua parcela na lesão por todos ocasionada, o que, por óbvio, não solucionaria o problema da degradação àquele bem. 


\section{Conclusão}

O desenvolvimento tecnológico, percebido principalmente no último século, trouxe junto um imenso revés para todo o planeta, consistente na degradação dos recursos naturais, e em uma velocidade assustadoramente acelerada, o que acarreta na impossibilidade do meio de restabelecer naturalmente o status anteriormente existente.

Teme-se hoje pela ausência, em um futuro próximo, de recursos e fatores naturais indispensáveis à manutenção da vida em nosso planeta. Muito se discute hoje, por exemplo, acerca da potabilidade da água e dos malefícios ocasionados pelo aquecimento global, decorrente primordialmente da atividade humana.

O homem muitas vezes se apresenta como um voraz e insaciável predador do meio no qual está inserido, tomando para si tudo aquilo que julga necessário a sua própria satisfação, colocando em cheque sua própria existência, isso em uma visão estritamente antropocêntrica, desconsiderando os demais seres vivos que igualmente são afetados por esta prática predatória.

Se por um lado o desenvolvimento da humanidade se faz necessário, e sendo igualmente verdadeira a afirmação de que se torna impossível cogitar de desenvolvimento sem utilização dos recursos naturais existentes no planeta, por outro lado se faz necessário um arcabouço jurídico destinado a tutelar as relações entre o homem explorador e o meio ambiente.

Neste contexto podemos afirmar ser muito avançada nossa legislação em matéria ambiental, tendo recebido tratamento constitucional a partir da promulgação da nossa Carta Magna em 1988, o que demonstra irrefutavelmente a importância da proteção do meio ambiente, bem de uso comum do povo, para a própria sobrevivência da espécie humana.

Neste processo de proteção do meio ambiente um importante papel desempenha o instituto da responsabilidade civil, tradicionalmente 
concebida com a finalidade de tornar possível a restituição de uma lesão injustamente provocada.

Porém, em matéria ambiental, além da restituição do estado anterior à ocorrência do dano, a responsabilidade civil ganha alguns outros contornos e peculiaridades, não sendo mais um instituto destinado simplesmente à reparação de um dano causado.

Muitas vezes, como tivemos a oportunidade de observar, a reparação se torna muito difícil, quando não impossível, tornando imperativo o direcionamento da ordem jurídica para uma conduta humana no sentido de impedir, tanto quanto possível, o dano ambiental.

Surge a idéia da prevenção, um dos princípios basilares do direito ambiental, uma vez que, além de menos oneroso, tanto para o explorador de uma atividade potencialmente poluidora quanto para a coletividade, muitas vezes se apresentará como única medida satisfatória na preservação da qualidade ambiental, seja para as atuais gerações, seja para as futuras.

Desta forma, um rígido sistema reparatório terá como um dos principais objetivos o direcionamento das atividades potencialmente poluidoras no sentido de tentar ao máximo evitar a ocorrência de um passivo ambiental, pois quando este restar configurado o fardo a ser suportado será bem pesado.

Com este pensamento, em 1981 foi editada a Lei de Política Nacional do Meio Ambiente, a qual normatizou um conceito fundamental para a completa reparação, e porque não também dizer prevenção, dos danos ambientais, tornando a responsabilidade civil nesta matéria objetiva, fundada no risco da atividade, destituindo-a de qualquer valoração acerca da culpa do causador do dano.

Com isso, verificando-se o dano, bem como uma conduta (comissiva ou omissiva) que para a ocorrência deste tenha contribuído, estará 
configurada a necessidade de reparação do meio ambiente lesado por parte deste agente.

Porém o tema ainda não havia sido exaurido, pois ainda restaria estabelecer sobre qual das diversas teorias que fundamentam a responsabilidade civil objetiva se estabeleceria o dever de indenizar quando da ocorrência de um dano ao meio ambiente.

Dessa maneira, levando-se em consideração a importância do bem aqui tutelado, bem como a gama de seres vivos que com sua lesão se veriam prejudicados, defendemos aqui a aplicação do modelo mais gravoso dentre as diversas teorias do risco, que é a teoria do risco integral.

Como afirmamos, de acordo com esta teoria nenhuma das diversas excludentes de responsabilidade, como o caso fortuito ou a força maior, por exemplo, representariam um obste à completa e efetiva reparação do meio ambiente lesado, pois ainda assim persistiria o dever de reparar.

Os diversos agentes passivos estarão submetidos a todo e qualquer risco decorrente de sua atividade, não lhes sendo possível alegar em seu favor nenhuma causa que os exima de reparar o dano ambiental.

Não obstante o nível de preocupação com o meio ambiente que hoje presenciamos, esperamos observar com este sistema de reparação uma efetiva e considerável alteração no quadro de degradação hoje suportado, servindo não só como uma forma de restituir o status quo do bem lesado, mas também como fonte de profundas transformações culturais concernentes à necessidade de se preservar o meio através do qual nossa sobrevivência está atrelada. 


\section{Bibliografia}

1) ANTUNES, Paulo de Bessa. Direito ambiental. 7. ed. Rio de Janeiro: Lúmen Juris, 2004.

2) ATHIAS, Jorge Alex Nunes. Responsabilidade civil e meio ambiente: breve panorama do direito brasileiro. In: Dano ambiental: prevenção, recuperação e repressão. São Paulo: Revista dos Tribunais, 1993.

3) BENJAMIN, Antonio Herman V. Responsabilidade civil pelo dano ambiental. Revista de Direito Ambiental, São Paulo, n. 9, p. 5-52, jan/mar. 1998.

4) BRASIL. Superior Tribunal de Justiça. REep $n^{\circ}$ 442.586. Recorrentes: Rede Bandeirantes de Postos de Serviços Ltda. Recorrido: Companhia de Tecnologia de Saneamento Ambiental - CETESB. Rel: Ministro Luiz Fux, Brasília, 26 nov. 2002. Disponível em: $<$ http://www.stj.gov.br $>$. Acesso em: 6 jun. 2005.

5) BRASIL. Superior Tribunal de Justiça. REep $n^{\circ}$ 18.567. Recorrente: Solorrico S/A Indústria e Comércio. Recorridos: OIKOS - União dos Defensores da Terra e Ministério Público do Estado de São Paulo. Rel: Ministra Eliana Calmon, Brasília, 16 jun. 2000. Disponível em:

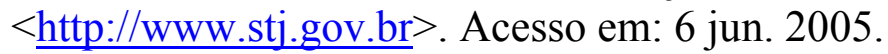

6)BRASIL. Superior Tribunal de Justiça. REep $n^{\circ}$ 37.354-9. Recorrente: Freitas Guimarães Projeto e Construção Ltda. Recorrido: Ministério Público do Estado de São Paulo. Rel: Ministro Antônio da Pádua Ribeiro, Brasília, 30 ago. 1995. Disponível em: <http://www.stj.gov.br>. Acesso em: 6 jun. 2005.

7) CAVALIERI FILHO, Sergio. Programa de responsabilidade civil. 5. ed. rev. aum. atual. São Paulo: Malheiros, 2004.

8) MACHADO, Paulo Affonso Leme. Direito ambiental brasileiro. 12 ed. São Paulo: Malheiros Editores, 2004.

9) MILARÉ, Édis. Direito do ambiente. 2. ed. rev. aum. atual. São Paulo: Revista dos Tribunais, 2001. 
10) MIRRA, Álvaro Luiz Valery. Princípios fundamentais do direito ambiental. Revista de Direito Ambiental, São Paulo, n. 2, p. 50-66. 1996.

11) NERY JÚNIOR, Nelson; NERY, Rosa Maria B. B. de Andrade. Responsabilidade civil, meio-ambiente e ação coletiva ambiental. In: DANO ambiental: prevenção, recuperação e repressão. São Paulo: Revista dos Tribunais, 1993.

12) PASQUALOTTO, Adalberto. Responsabilidade civil por dano ambiental: considerações de ordem material e processual. In: DANO ambiental: prevenção, reparação e repressão. São Paulo: Revista dos Tribunais, 1993.

13) SAMPAIO, Francisco J. Marques. Meio ambiente no direito brasileiro atual. Curitiba: Editora Juruá, 1993.

14) STEIGLEDER, Annelise Monteiro. Responsabilidade civil ambiental: as dimensões do dano ambiental no direito brasileiro. Porto Alegre: Livraria do Advogado, 2004. 